\title{
Post-pandemic lifestyle changes and their interaction with resident behavior in housing and neighborhoods: Bursa, Turkey
}

\author{
Miray Gür ${ }^{1}$ (D)
}

Received: 22 February 2021 / Accepted: 27 August 2021 / Published online: 4 September 2021 (c) The Author(s), under exclusive licence to Springer Nature B.V. 2021

\begin{abstract}
COVID-19 pandemic has re-raised questions about healthy housing and residential environments. The aim of this study is to examine lifestyle changes during the pandemic and their reflections in the use of housing. The study also compares households on different socioeconomic levels in Bursa, the study area. Bursa is a Turkish metropolis that was affected by the spread of COVID-19. Data were collected from 500 residents of 30 neighborhoods in the city's three most populous districts, Osmangazi, Nilüfer and Yildirim. The participants were selected using stratified sampling and interviewed face-to-face using questionnaires. Reliability analysis, frequency distributions, descriptive statistics, ANOVA and the chi-squared test were used to evaluate the data. The results indicate that the participants' hygiene habits, shopping behaviors, transportation habits and frequency of their contact with neighbors and friends have changed. Most of the participants live in apartments, and they need flexible designs that can be used for different purposes. They need toilets and ventilation spaces at the entrances of their homes. The use of balconies has increased. During the pandemic, the use of urban green spaces decreased in general, and the use of open areas around homes increased. High-income residents have advantages in terms of lifestyle, housing and residential environments, so their awareness about and observance of pandemic rules were higher. Lifestyles, housing, residential environments and urban opportunities differ as a result of socioeconomic segregation, and lower-income residents are more vulnerable to disease. Future studies should consider potential risks to humanity in order to address the housing-related problems of disadvantaged groups.
\end{abstract}

Keywords COVID-19 $\cdot$ Lifestyles $\cdot$ Residential environments $\cdot$ Housing unit $\cdot$ Resident behaviors $\cdot$ Socioeconomic status

Miray Gür

miraygur@yahoo.com

1 Department of Architecture, Bursa Uludağ University, Görükle Campus 16059, Nilüfer, Bursa, Turkey 


\section{Introduction}

The COVID-19 pandemic forced changes in lifestyles around the world in 2020, profoundly altering our daily lives. It broke out in China in December 2019, and due to many deaths in a short time, it was declared a pandemic by the World Health Organization (WHO) on March 11, 2020. On the same day, the first case was detected in Turkey. Hoping to contain the spread of the virus, quarantines and lockdowns were implemented in many countries, and schools were closed. In the first months of 2021, vaccination programs were initiated in various countries; while on the other hand, the constant mutation of the virus is threatening human lives.

While COVID-19 has spread and receded at different paces in different places, national and regional governments have mainly used lockdowns to prevent its spread (Gondauri et al., 2020; Signorelli et al., 2020). They have established social distancing rules that have restricted socializing, business and school life. The multidimensional effects of these practices have had important and worldwide effects on psychological health, social relations and economics. Studies in a variety of disciplines have described economic fluctuations due to COVID-19 and lockdowns in different countries, as well as their effects on healthcare workers, mental health, education and work (Fernandes, 2020; Greenberg, 2020; Ozili \& Arun, 2020; Talevi et al., 2020; Yao et al., 2020).

The pandemic has had effects on every level and scale, including individuals, communities, organizations, governments, housing, workplaces, neighborhoods and public spaces (Salama, 2020). Forcing people to stay in their homes causes a wide-ranging suite of issues and challenges (Rogers and Emma 2020). The COVID-19 pandemic has caused individual and social problems, but problems with space have also become fundamental. Beyond mere shelter, homes have begun to acquire a variety of roles, including workplace, school, gym, restaurant, laundry, theater and even town square. This has made their utility and design even more vitally important (Garber, 2020). Due to COVID-19, healthier, safer and more resilient homes has come to mean homes that improve the well-being and living conditions of their occupants while reducing the risk of contagion (Signorelli et al., 2020).

It is important for future education and research in, and the practice of architecture and urban planning to elucidate ambiguous design decisions because architecture and urban planning will shape developments in post-pandemic urban spaces. The immediate research areas that require new insights into the socio-spatial implications of COVID-19 include: urban dynamics during and after COVID-19, the socio-spatial implications of social distancing measures, and the requirements of new spatial environments to accommodate emerging living and work patterns (Salama, 2020). The utility and design of homes affect daily life much more than they did before the pandemic, and needs to be reevaluated and designed for changing needs. The housing choices made now will have far-reaching consequences. These effects should be investigated scientifically in the short, medium and long term by housing researchers (Rogers and Emma 2020).

It is still uncertain whether it will be possible to return to the 'normal' pre-pandemic lifestyle, and this shows that pandemics, wars and disasters are a concrete part of life. Therefore, studies are needed to determine lifestyle trends, problems and needs, and the suitability of housing and residential environments during the COVID-19 pandemic. Changed lifestyles have disrupted the balance of home and work life, daily lives that were lived at the urban scale have had to fit into the scale of single homes. Behaviors in housing and residential environments have changed. Urban spaces, housing and residential environments need to keep pace with the changes in urban and daily life. The aim of this study is 
to examine lifestyle changes during the pandemic and their effects on the use of housing and residential environments during the COVID-19 pandemic. It also compares households at different socioeconomic levels in different districts, and discusses the literature on the pandemic's effects on lifestyles and habits, and the changing meaning of the housing and housing expectations. The results of field study in Bursa are intended to support deductions about adopting housing and residential environment policies that support all people during the pandemic.

\section{Pandemic lifestyles and habits}

The COVID-19 pandemic has familiarized us with concepts such as social distancing, curfews, isolation, quarantine, disinfection and lockdowns. Governments have tried to raise individual and social awareness, and lockdowns have been implemented to slow the spread of the virus (Olivier et al., 2020; Sarla, 2020). Some studies have found that awareness about the disease varies by age and occupation, and that young people are more aware (Alqahtani \& Aldawsari, 2015; Nooh et al., 2020; Zegarra-Valdivia et al., 2020). Education affects awareness and knowledge because more education means more knowledge (Nooh et al., 2020; Zegarra-Valdivia et al., 2020).

Awareness is not enough to prevent the spread of COVID-19. It is very important to comply with the warnings by the WHO, governments and scientific committees. Social distancing, wearing medical masks, avoiding touching the face and careful hand hygiene are the most important ways to prevent the spread of the virus (WHO 2020; Sarla, 2020), but awareness increases hygiene practices and social distancing (Alahdal et al., 2020; Al-Hasan et al., 2020). It has also been reported to increase social distancing, handwashing, minimal touching, home disinfecting and the wearing of masks significantly (Sadiq et al., 2020). Information sources such as social media, the internet, TV and newspapers positively affect social distancing (Al-Hasan et al., 2020). While the frequency of handwashing in Poland has increased by a factor of nearly three during the pandemic, studies of social distancing and handwashing have found that they vary with age, gender and socioeconomic level. The awareness levels of different ages and genders and their attention to wearing masks also vary (Nooh et al., 2020; Sakr et al., 2020; Weill et al., 2020). Sadiq et al. (2020) found no variation with education or profession, but Wise et al. (2020) concluded that younger people, more educated people and females paid more attention to protective behaviors.

Inequalities are an important issue in the spread of the disease. Most low-income households in India do not have handwashing facilities (Guilomoto \& Licart, 2020). Low-income communities pay less attention to social distancing, and this is attributed to work conditions. Higher income groups can work remotely, which allows them to be more careful (Baker et al., 2020; Głąbska et al., 2020; Weill et al., 2020). Similarly, in densely populated spaces in the United States, Latino and Asian neighborhoods are more vulnerable to economic difficulties and disease than White neighborhoods due to residential segregation and concentrated poverty (Jones \& Grigsby-Toussaint, 2020).

The pandemic has also affected education, social relationships, nutrition and physical activity (Settersten et al., 2020). One study found that the lockdowns cause psychosocial strain and significantly reduce social activities with family, friends and neighbors. On the other hand, social contact by means of digital technologies has significantly increased (Ammar et al., 2020). A study conducted in Canada found similar results (Ellis et al., 2020). Isolation in China had negative psychological effects on most people, creating an 
anxious and tense mood (Qiu et al., 2020; Wang et al., 2020). In addition to the contribution of physical activity to health, it has been proven to strengthen the immune mechanism during the COVID-19 pandemic. Physical activity improves common chronic conditions that increase the risk for severe COVID-19 (Mattioli et al., 2020; Pieh et al., 2020). Lack of physical activity during quarantine, unhealthy lifestyles and anxiety raise the risk of cardiovascular disease (Mattioli et al., 2020). The pandemic changed nutrition and physical activities, and sports habits increased or decreased in different nations. In Australia, lockdowns increased people's physical activity levels and reduced their tendency to overeat (Owen et al. 2021). In Italy, physical activity levels increased (Di Renzo et al., 2020). The body weights of people who did not do physical exercise increased in Spain (López-Moreno 2020). In France, increased body weight was associated with socioeconomic levels, and low-income groups were found to consume unhealthy foods (Reyes-Olavarría et al. 2020). There is little opportunity for physical exercise in low-income neighborhoods, and people there walk for transportation in areas that are less attractive for walking and with less social support (Giles-Corti \& Donovan, 2002). Another study found that low-income neighborhoods are deprived of environments offering physical activity opportunities than those with high incomes (Estabrooks et al. 2006).

The pandemic also affected the use of public transport. Many people have stopped using public transport. Studies in Sweden and Switzerland found that the population is now less likely to use space-efficient large vehicles such as buses, trams and trains (Jenelius \& Cebecauer, 2020; Molloy et al., 2020). Compared to 2019, the use of public transport fell by $20 \%$, while car travel and walking increased in Zurich (Molloy et al., 2020). Low-income groups are at a disadvantage. A study conducted in the US found that low socioeconomic levels and public transport use increased the spread of the disease. The use of subways by essential and healthcare workers increased, which was associated with a higher prevalence of COVID-19. While public transport use decreased in high-income areas, the positive test ratio increased, especially in low-income groups that have to go to work (Sy et al., 2020).

Other factors that affect housing use are distance education and online shopping. Distance education has become common in many nations and educational fields during the COVID-19 pandemic (Chen et al., 2020; Hebebci et al., 2020; Sindiani et al., 2020). More people staying at home and avoiding crowded shopping places has increased online shopping in most countries. Shopping behavior has changed considerably, especially due to strict lockdowns such as those in the US and China (Arora et al., 2020). As it has in other countries, staying home and social isolation has increased online shopping in Turkey (Çakiroğlu et al., 2020), where the numbers of online shoppers in almost all sectors are increasing every day (Demirdöğmez et al., 2020; Kayabaşi, 2020). It is seen in different countries that especially higher educated people and women tend to shop online (Alaimo et al., 2020; Hashem, 2020). Coronavirus remains active, stable and infectious for $72 \mathrm{~h}$ on cardboard and plastic. This means that products ordered online can bring coronavirus into people's homes (Sarla, 2020). The rising number of online shoppers increases the importance of not bringing packages directly into the house. 


\section{Housing, residential environments and lifestyle changes during the Covid-19 pandemic}

It is inevitable that we reexamine the built environment to prevent the spread of the COVID-19 virus. The built environment, interactions between individuals, viral transmission through the air and on materials all play an important role in the spread of COVID-19 (Amerio et al., 2020; Dietz et al., 2020). For this reason, airing out packages, groceries and clothing worn outside the home has become common. Architectural and interior design affects the types of bacteria humans transport into buildings, and ventilation shapes microbial communities (Adams et al., 2016; Kembel et al., 2014). In addition to design features, the movement of particles on surfaces and in the air creates risks due to occupancy and activities (Adams et al., 2016). Since the virus can easily spread in crowded environments, moving from crowded workplaces and schools to the home has been the quickest and safest solution. Thus, housing is critical in preventing the spread of the virus, in addition to community buildings such as health care facilities (Megahed \& Ghoneim, 2020). Built environments are key determinants of health as resources, due to site planning and for incorporating green spaces (Andreucci et al., 2019). Although housing is a basic human right, people with low incomes have housing problems such as lack of space and lack of security. They have also not been conscientious enough about social distancing during the pandemic (Oluwatosin et al., 2020). People who share housing often gather together for activities and may have challenges with social distancing (https://www.cdc.gov/).

Social distancing has changed the meaning of the word, crowded. While the WHO says that $1.5-2 \mathrm{~m}$ of distance is required to prevent the risk of infection, other research has specified $2 \mathrm{~m}$ as the distance needed to minimize the risk of infection (Setti et al., 2020). During the pandemic, crowdedness should refer to two spatial scales, the urban and the residential. Crowded does not only mean a mismatch between the number of residents and the size of the house. It is also associated with the age, relationships and gender of the people who share a dwelling (Amerio et al., 2020; Capolongo et al., 2020; D’Alessandro et al., 2020). The future of cities will involve a renewed focus on architectural and urban solutions that enable people to socialize without crowding (Sennett, 2020; Shenker 2020).

By minimizing interaction with urban space, lockdowns have increased the importance of housing and residential environments. It has become necessary to adapt the interiors of residences to their occupants' new lifestyles. Due to COVID-19, uncrowded, high-quality homes with fresh air and access to the outdoors typify healthy and livable residential environments. Housing layout, space, crowding, shelter, safety and indoor air quality have been reexamined during the COVID-19 pandemic, which may turn out to be a catalyst for healthy housing and sustainable building (Megahed \& Ghoneim, 2020). Peters and Halleran (2020) indicate the importance-post-pandemic-of health-promoting apartment housing design, window placement and views that alleviate stress, lighting levels that satisfy multiple residents, bedrooms designed for restful sleep, living rooms with better indoor air quality, access to nature, unit sizes and layouts that enable social distancing and prevent crowding. Comfortable, private spaces for study and work have become important for parents and children. Thermal comfort and energy efficiency have also become more important because people are spending more time in their homes (Hipwood, 2020). Indoor air quality has become the main problem, and built environments have become a threat to social distancing (Dietz et al., 2020). In this context, the design parameters of both home interiors and residential environments should be redefined. These parameters at both spatial scales for healthy, safe and sustainable housing 
are associated with design features such as more visible and accessible green spaces, flexible and adaptable living spaces and sustainable architecture. Other important parameters are related to management, design and implementation, thermal comfort and indoor air quality, water consumption, wastewater and solid waste management, housing automation and building materials (D'Alessandro et al., 2020). During the pandemic, skylights, large windows, rooftop patios, balconies and courtyards have been critically important for better air quality (Megahed \& Ghoneim, 2020). Small elements of home design have had significant consequences for people in quarantine. Issues such as the number of rooms, the availability of the internet, dishwashers, washing machines, exercise facilities, cooking and fresh air have become very important as homes became the setting for everything that people do (Garber, 2020). Flexible living spaces have become a necessity so that homes have spaces for physical exercise, relaxation and children's play (Capolongo et al., 2020; D’Alessandro et al., 2020). Homes' interiors have become determinants of their occupants' behavior. The increased popularity of distance education around the world has led to some difficulties in housing. The continuous control of parents over children has caused trouble for both parents and children. A study conducted in Saudi Arabia found that, in this culture, family members of different generations feel discomfort in their homes due to the presence of many children. Problems such as pandemic-related stress, anxiety, depression and domestic violence have emerged for both teachers and students (Al Lily et al., 2020). Most of the families in Czechia are involved in home educating their children (Brom et al., 2020). According to an international study, the success of distance learning is affected by their home environments, and students who do not have a space for studying in small houses are at a disadvantage (Bayrakdar \& Guveli, 2020).

Poor quality interiors increase depressive symptoms during lockdowns. While the quality of interior living spaces is very important, green spaces in residential environments have become important for mental health (Amerio et al., 2020; Andreucci et al., 2019). Changing preferences and expectations about green spaces has the potential to lead new design decisions regarding the residential environments. This includes recreational areas, running paths and green spaces for socially distanced physical exercise (Honey-Rosés et al., 2020). The quality of walking environments is important for neighborhoods (GilesCorti \& Donovan, 2002). Green areas close to housing should offer opportunities for everyone to exercise as a way of supporting their health (Edwards \& Tsouros, 2008). People with higher incomes live in places that allow for better walking and exercise activities (Estabrooks et al. 2006; Giles-Corti \& Donovan, 2002). It has become even more important for residential environments to offer open areas that are suitable for socially distanced exercise. Urban green spaces also have beneficial effects on mental disorders and stress. The COVID-19 pandemic has made it clear that people who do not have access to green spaces should view greenery or grow plants in their homes (Andreucci et al., 2019). People's need for fresh air in cities has increased the importance of balconies and patios (Poon, 2020; Türkoğlu, 2020). Balconies in Italian neighborhoods have become spaces for safe socialization, musical communication and supporting people's solidarity (Calvo \& Bejarano, 2020).

Studies have shown that homes and residential environments have a pronounced effect on life satisfaction. The factors that affect satisfaction and overall quality of life are: layout, interior space, meeting requirements, open areas and equipment that enrich living (Türkoğlu, 1997; Amerigo and Aragones 1997; Bonaiuto et al., 2003). During the COVID19 pandemic, housing, which is a human right, should be adaptable to new lifestyles and supports more efficient and healthy living. Considering the potential risks to humanity in 
the future, housing and residential environments should be reconsidered from the perspective of changing lifestyles.

\section{Data and methodology}

\subsection{The aim and steps of the study}

The COVID-19 pandemic caused sharp and sudden changes in daily routines as hygiene, education, work, transportation, physical activities and dietary habits. The fact that family members of different age groups had to perform their respective activities, such as education, housework, gaming or business, in the same space changed the meaning of housing and housing environment and increased the importance of these two concepts. Accordingly, as summarized in Fig. 1, the research problem focused on identifying the changes to lifestyles after the pandemic, the interaction between housing, housing environment and lifestyles, and the impact of the housing environment location.

The aims of this study in the context of the research problem are; (a) to examine lifestyle changes during the pandemic, (b) to investigate the relationship between changing lifestyles and the characteristics of housing and residential environments, (c) to examine behavior changes in usage of housing, (d) to investigate the relationship between user behaviors and the characteristics of housing and residential environments, and (e) to compare resident behaviors in different districts according to different socioeconomic groups and development level. In line with the aims of this study, residents' post-pandemic lifestyles and the changed dynamics of the neighborhoods in Bursa played a key role in determining the hypotheses. These dynamics, which are explained in detail in later parts of this article, differ physically and socio-economically. In brief, they include housing typology, opportunities offered by the environment, and educational level and socio-economic status of the social group in the districts. The resident behaviors observed through on-site investigations and studies on pre- and post-pandemic housing, health and lifestyles contributed to the efforts to determine the hypotheses.

The main hypotheses developed in line with the aims of the study were as follows: (a) the habits associated with the residents' lifestyles change after the pandemic; (b) housing type has an impact on the use of green spaces (an increase was assumed in the number of detached houses and housing sites); (c) physical activity frequency and green space use differ in neighborhoods and districts based on changing opportunities (it was assumed that the use of green spaces and physical activities were higher in more planned residential areas and in places with a greater presence of higher socio-economic status (SES) users); and (d) hygiene and social distance behaviors change according to the SES and awareness level of the users in different districts. In the next step, questionnaire items were developed to test the hypotheses. Field dynamics and studies in the literature played key roles in developing the items (Fig. 1).

The questionnaires were administered to a sample of 500 people living in different districts of Bursa, and statistical analyses were performed on the data gathered from the responses. Details on the preparation, implementation and statistical assessments the questionnaire are presented in Sect. 4.3, just after the part providing information on Bursa. A comparative assessment of the results was conducted in terms of changing lifestyles, demographic traits and housing environments, locations and their physical and socio-economic characteristics, and field observations and visuals. These were then discussed within the 


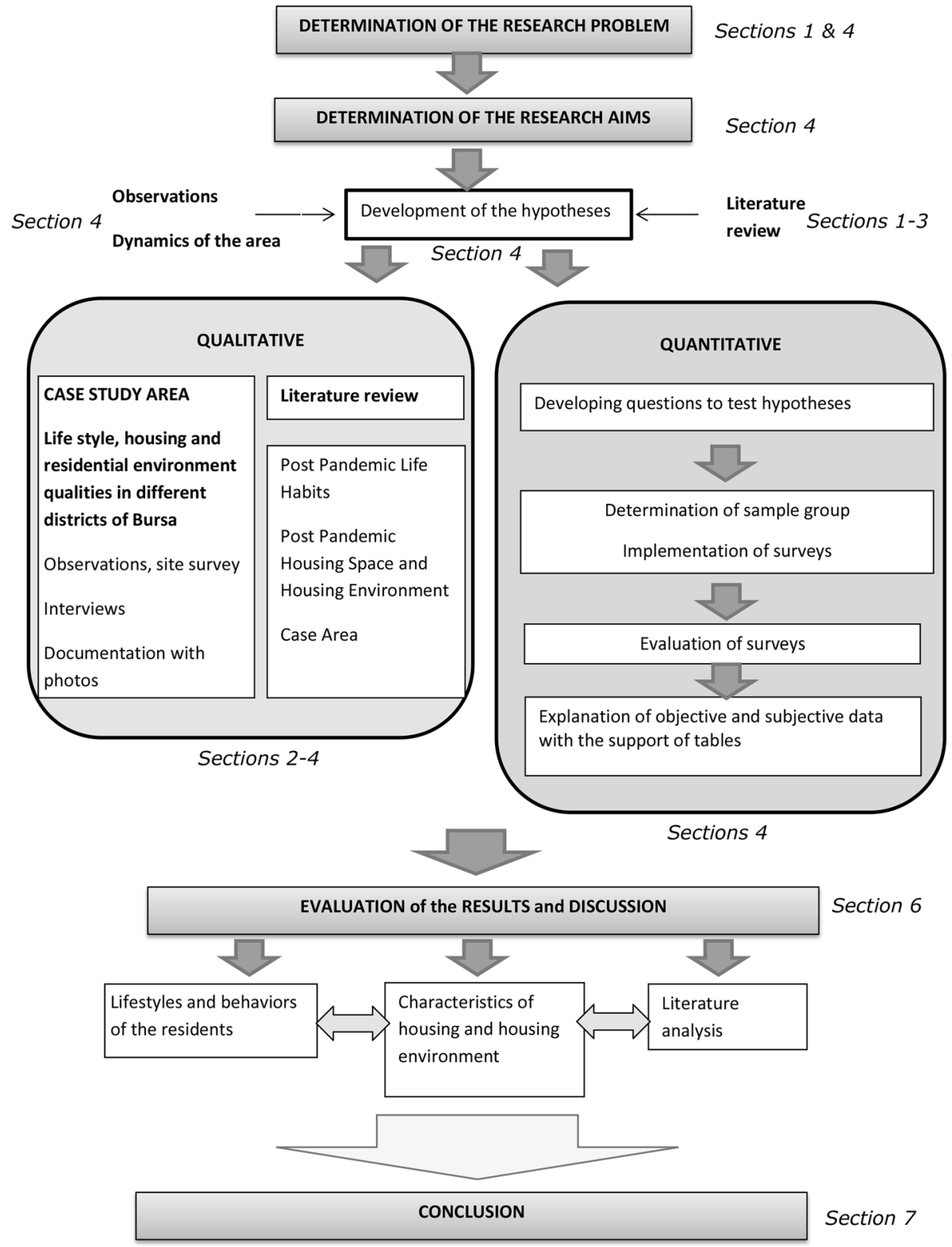

Fig. 1 Methodology and Steps of the Research 
framework of the results reported in the relevant literature, followed by the conclusions and suggestions made from the study results.

\subsection{The study area}

Turkey's fourth largest city, Bursa, was chosen as the study area. It is known for being on the UNESCO world heritage list. This study was conducted in 30 neighborhoods in three of Bursa's districts (Table 1). Bursa is an industrial city with 17 industrial zones, and it was one of the cities affected most by the spread of COVID-19, especially in its factories. With a population of over 3 million, Bursa is one of the provinces with the highest numbers of COVID-19 cases and deaths, especially in November and December 2020. This study was conducted in Bursa's three most populous districts: Osmangazi, Nilüfer and Yildirim. Figure 2 shows the geographical positions of the districts in the city, while Figs. 3 highlights in dark color the neighborhoods covered in the study.

Osmangazi is located in the center of Bursa. It is home to an important number of historical and cultural locations in Bursa included in UNESCO World Heritage List. According to the Socio-Economic Development Order of Turkish Districts prepared by the Turkish Ministry of Industry and Technology, the district of Osmangazi ranks 23rd among the first grade developed districts. These districts are particularly developed in terms of industry, technology and tourism, and their infrastructure is largely complete. Moreover, the medical services offered in these districts are of higher quality. While the rate of literacy and higher education/faculty graduates tend to be higher in the first-grade districts, it can vary from district to district (Y1lmaz et al., 2019). For example, in a study conducted in the district of Osmangazi, it was reported that $50 \%$ of the total sample group were elementary school graduates, $25 \%$ were secondary school graduates, and $15 \%$ had bachelor's and master's degrees, and in terms of income levels, most of the participants were found to have moderate and lower incomes (Gür, 2015). In a different study, it was shown that as urban people with high income levels have been gradually leaving the district, Osmangazi has been preferred by people with moderate incomes (Mutlu \& Varol, 2017). Other neighborhoods within the district, like Yildirim, have received intense Syrian migration. In other words, the residents are heterogeneous and predominantly low and middle income. In the old urban texture of the district, where reinforced concrete apartments and recent urban

Table 1 Case study neihborhoods

\begin{tabular}{lll}
\hline $\begin{array}{l}\text { Case Study Neighborhoods } \\
\text { Osmangazi }\end{array}$ & Nilüfer & Yildirim \\
\hline Bağlarbaşi & Balat & Arabayataği \\
Çekirge & Beşevler & Bağlaralti \\
Demirtaş Cumhuriyet & Çamlica & Değirmenönü \\
Emek Adnan Menderes & Demirci & Esenevler \\
Emek Fatih Sultan Mehmet & Dumlupinar & Hacivat \\
Güneştepe & İhsaniye & Millet \\
Hamitler & Karaman & Piremir \\
Küçükbalikli & Kültür & Şirinevler \\
Maksem & 23 Nisan & Ulus \\
Panayir & & Yavuzselim \\
Yunuseli & & \\
\hline
\end{tabular}




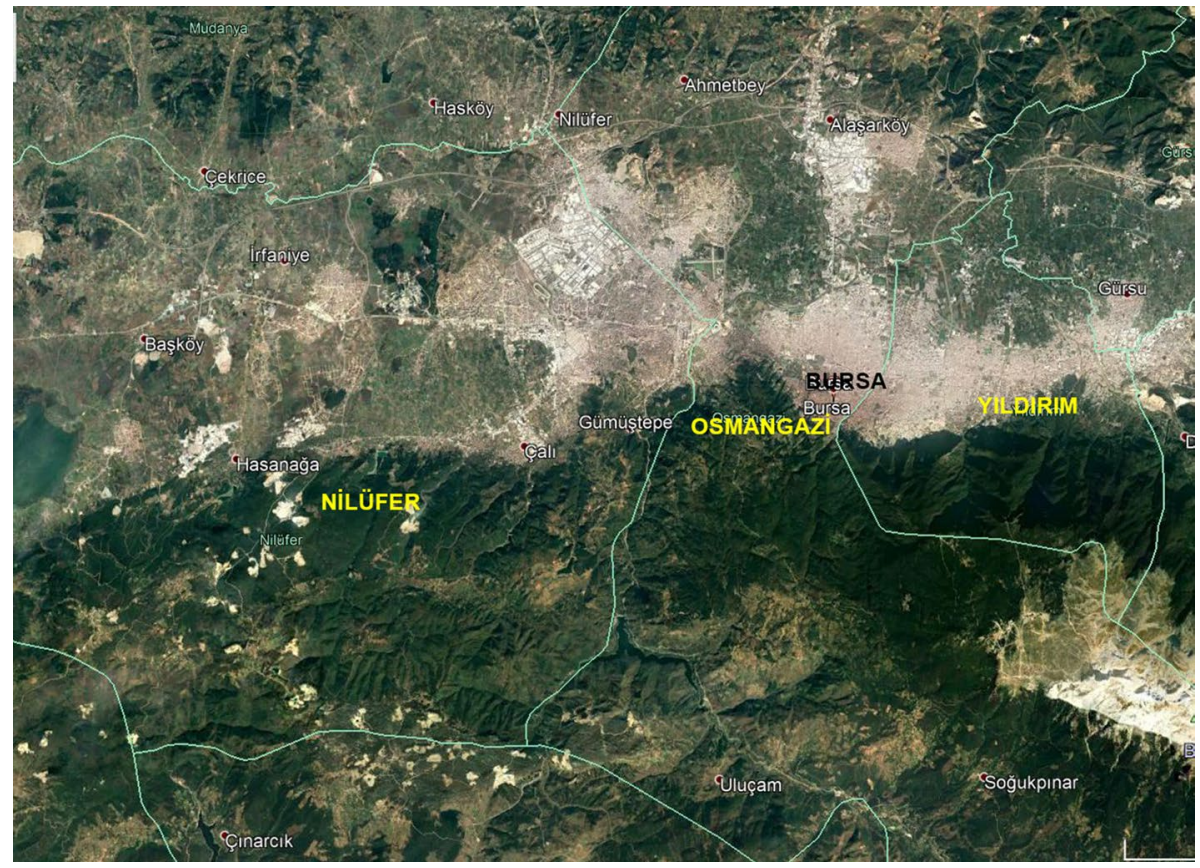

Fig. 2 Locations of Osmangazi, Nilüfer and Yildirim districts on Bursa Googe Earth Image

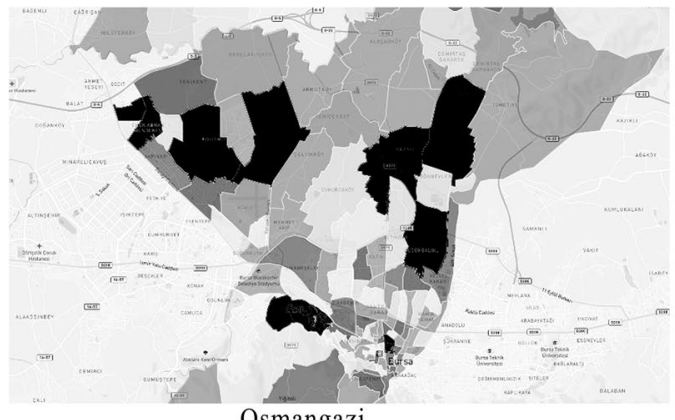

Osmangazi

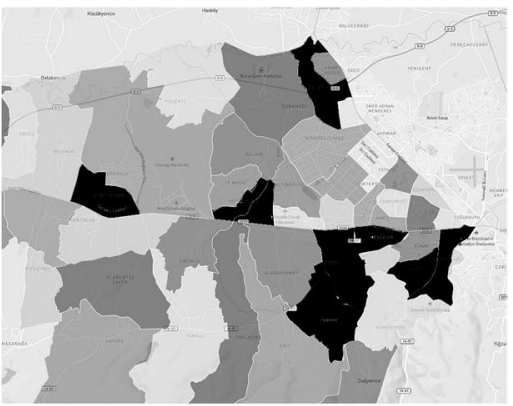

Nilüfer

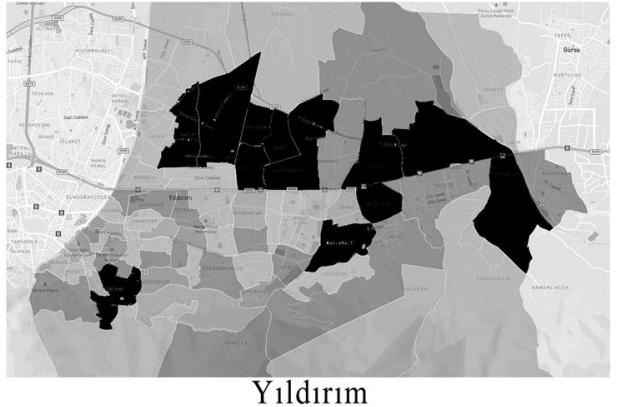

Fig. 3 Case study neighborhoods 


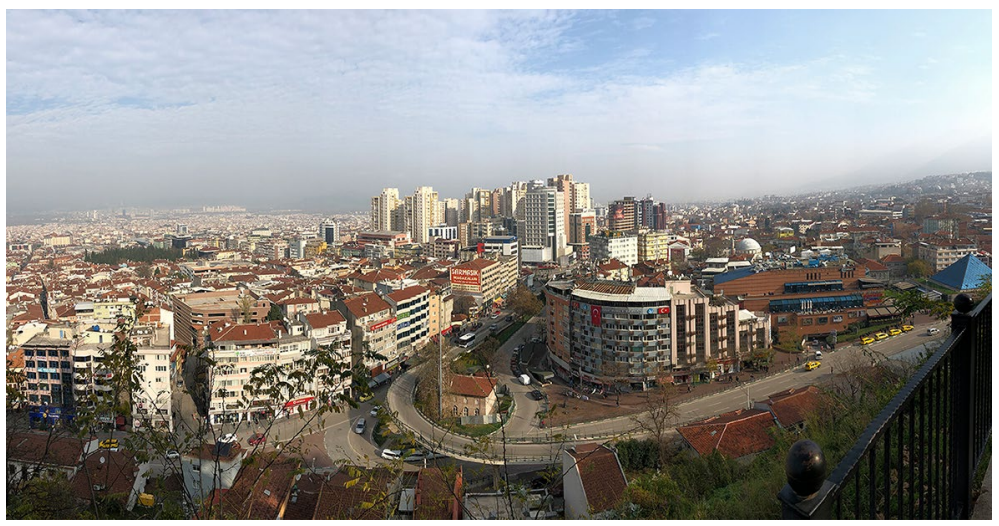

Fig. 4 An image from city center of Osmangazi District

transformations are prominent in the built environment, the topography includes narrow and sloping streets. Osmangazi is characterized by dense, mixed use neighborhoods, with planned and unplanned constructions found side by side one another. The photo in Fig. 4 presents the general appearance of the unplanned development in the area from Tophane Square in the urban center, where Bursa was established, to the district of Osmangazi. Figures 5 and 6 presents photographs of different housing environments from different times in the Maksem, Doğanbey and Çekirge districts in the urban center and in the Hamitler, Emek and Yunuseli districts that emerged as the city developed toward the west.
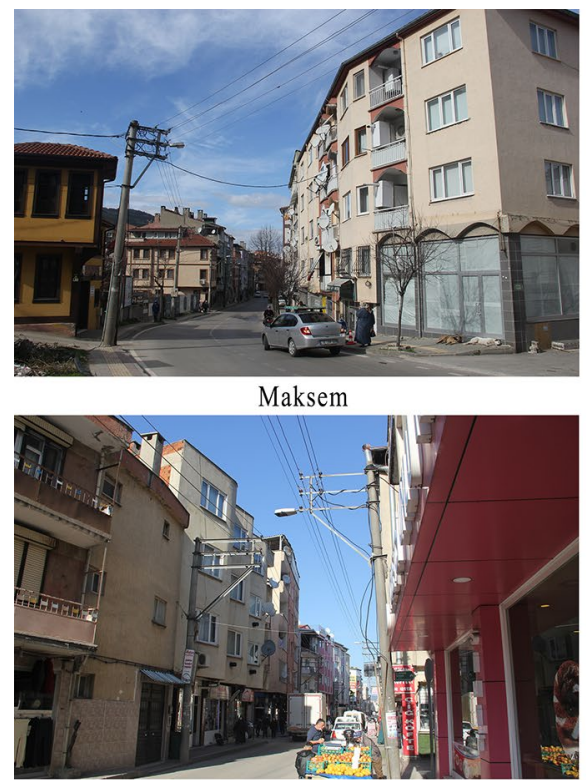

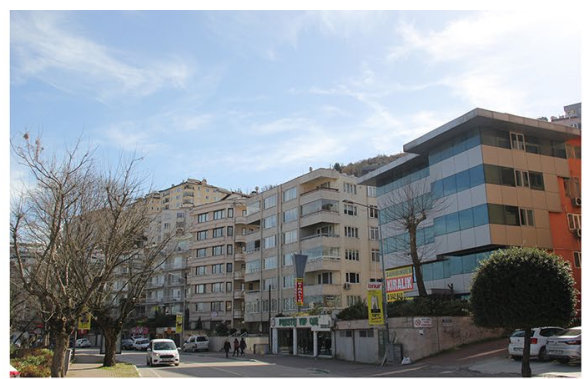

Çekirge

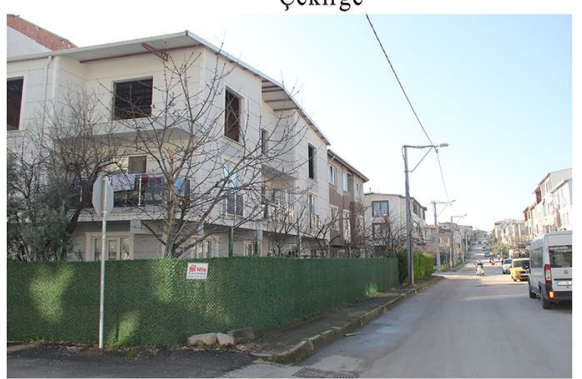

Hamitler

Fig. 5 Images from different housing environments \& typologies in Osmangazi District 

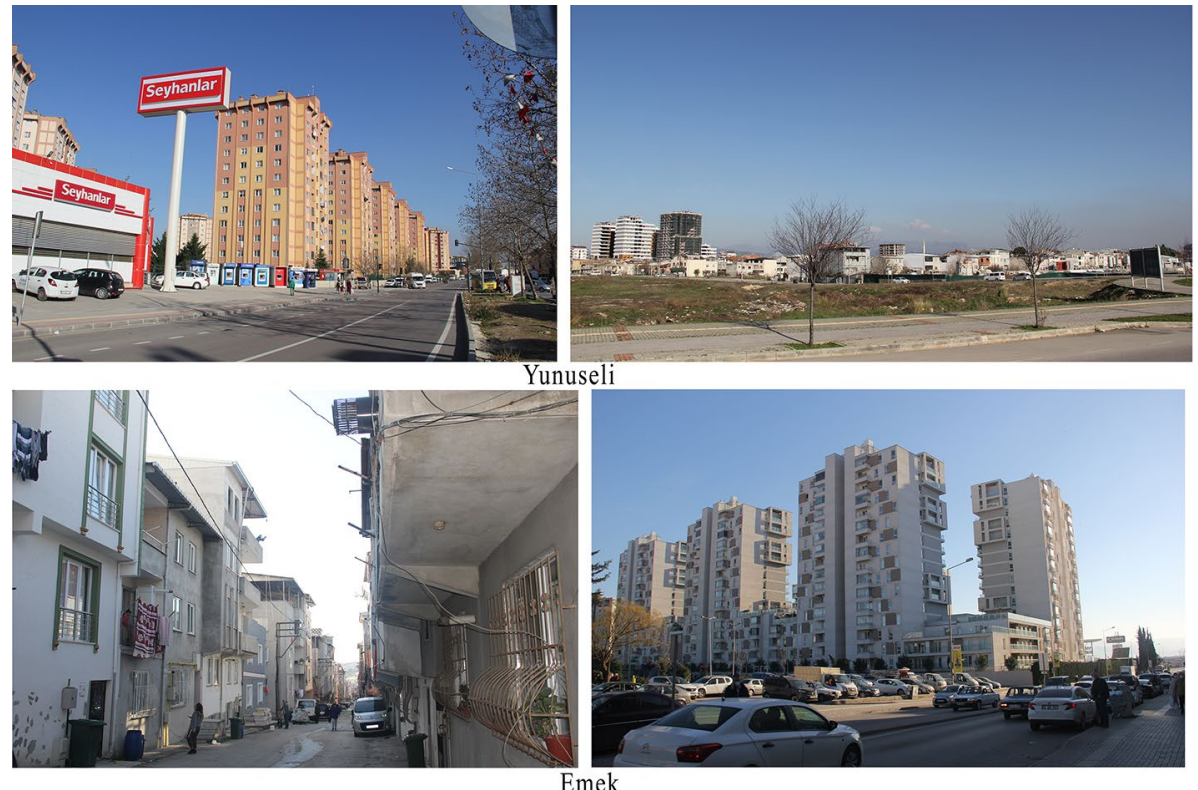

Emek

Fig. 6 Images from different housing environments \& typologies in Osmangazi District

Nilüfer is named after the Nilüfer River. It is Bursa's most prestigious residential district, and it was developed with a high level of urban planning. Nilüfer contributes significantly both to Bursa's economy and the national economy. Its industrial zones employ a majority of the city's population, and Bursa Uludağ University is located in this district. According to the Socio-Economic Development Order of Turkish Districts prepared by the Turkish Ministry of Industry and Technology, the district of Nilüfer is among the first grade developed districts, ranking 9th among them (Yilmaz et al., 2019). Most of Nilüfer's residents fall within the upper middle class, followed by the lower middle and upper class. In terms of total household income, the distribution of the residents is similar to that of the class structure (Mutlu \& Varol, 2017). The development in Nilüfer, which is a newer residential area compared to the districts of Yildirim and Osmangazi, has progressed with more planned policies. As a result, the housing typology largely consists of housing sites and gated communities, which over time attracted high to middle income groups and created a homogeneous structure. In other words, the population is predominantly middle and upper income and homogeneous. It is the most recently developed district in the city center and dominated by planned neighborhoods. Figure 7 presents photographs of the Beşevler, Demirci, Çamlica, 23 Nisan and Balat Neighborhoods, as well as different housing environments from different periods.

There are several historical heritage buildings in Yildirim on the skirts of Uludağ. Yildirim dates back to the Ottoman Empire, and is home to the Yeşil Complex and the Emir Sultan Mosque. The district of Yildirim in the east of the city has an unplanned housing texture and illegal buildings, which are often preferred by blue-collar workers coming from different regions of Turkey. According to the Socio-Economic Development Order of Turkish Districts prepared by the Turkish Ministry of Industry and Technology, Yildirim is among the second grade developed districts. These districts have a net positive migration rate, employment concentrated in the production, industry and 


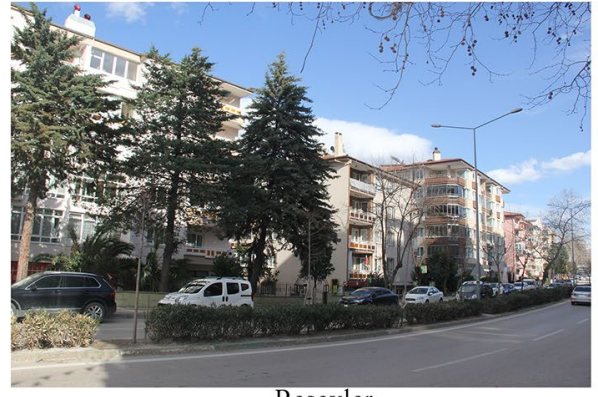

Beşevler

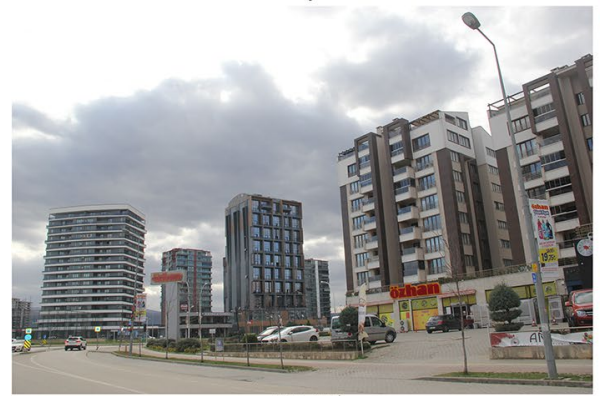

23 Nisan

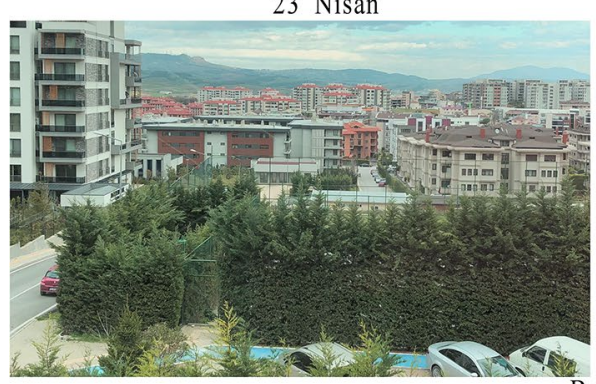

Balat

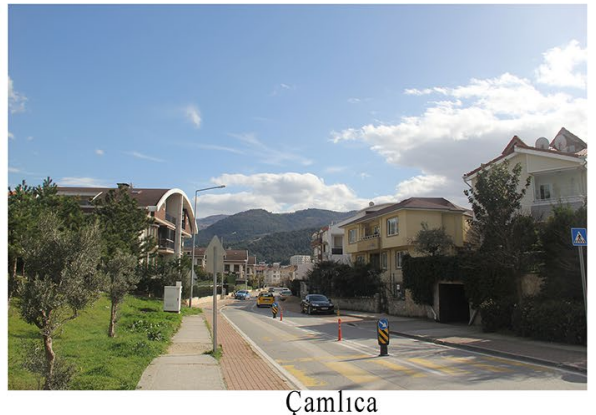

Çamlica

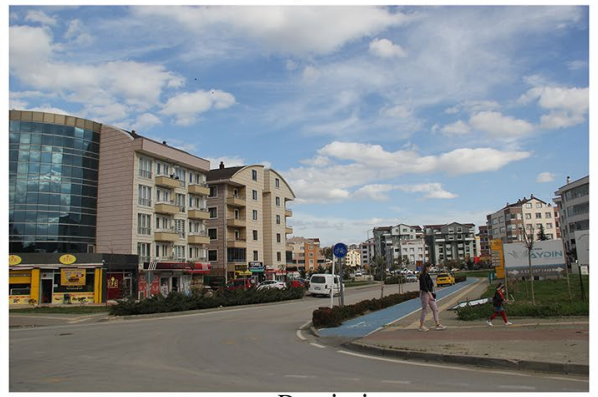

Demirci

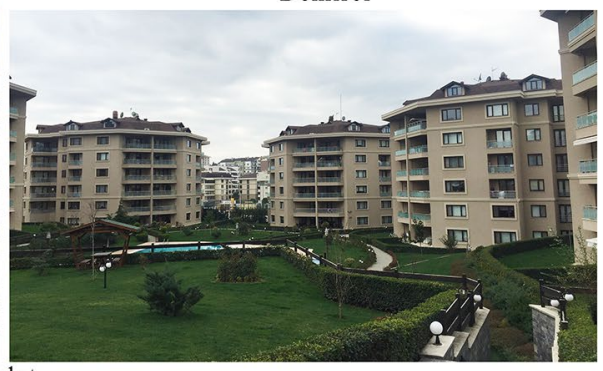

yi

Fig. 7 Images from Nilüfer District

service sectors, no tourism-related advantages and public services, and heterogeneous educational status and medical options (Yilmaz et al., 2019). In terms of the economic status of the residents, $39.5 \%$ had an income equal to or lower than the minimum wage, while $40 \%$ had a moderate-income level close to the minimum wage (Mutlu \& Varol, 2017). In other words, the district is mostly inhabited by middle and low-income groups and blue collar workers The groups coming to the illegal and non-developed housing areas through migrations live with their compatriots in the same neighborhoods. The social and technical infrastructure of these neighborhoods that lie within urban borders is insufficient, and urban transformation activities started with housing sites in the Millet Neighborhood. With the transformations, a significant segregation emerged in the urban texture (Fig. 8). Moreover, the migrations from Syria to Turkey increased the number of neighborhoods with Syrian migrants in Yildirim. There are large slums in Yildirim, which hosts most of Bursa's unplanned and illegal buildings, and blue-collar immigrant workers from various provinces live in them (Fig. 9). 

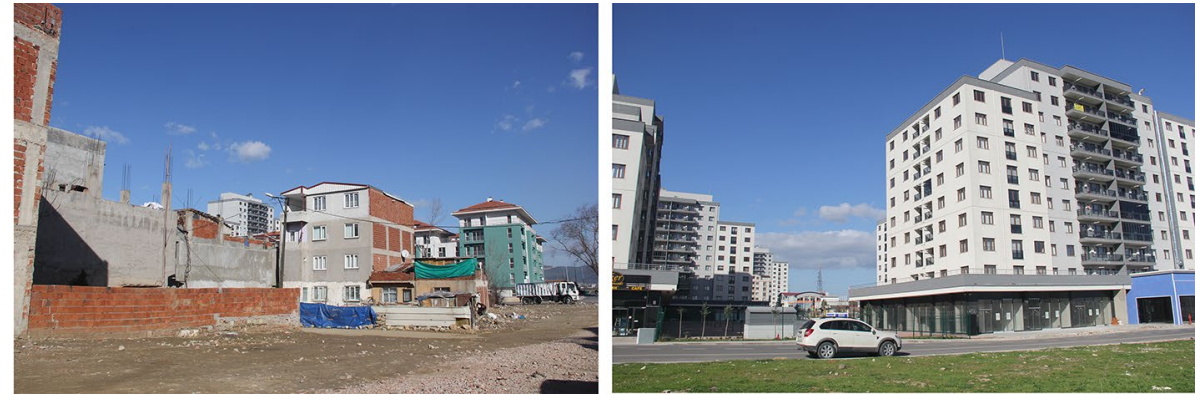

Fig. 8 The segregation in Millet Neighborhood
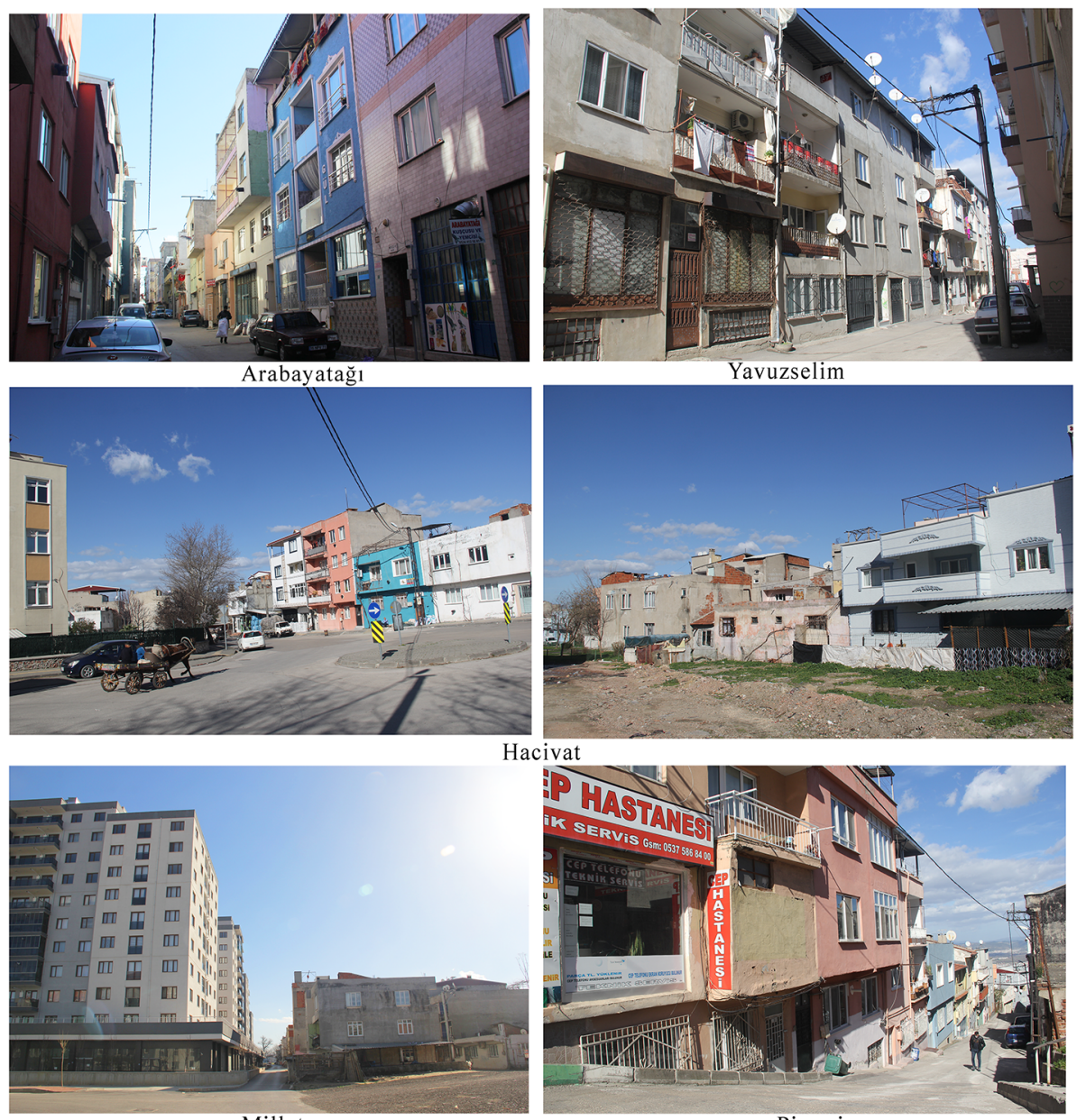

Fig. 9 Images from Yildirim District 
In terms of the socio-economic characteristics in Bursa, the main factor affecting spatial differentiation is the income level. The inequality in income level and wealth-related differentiation seen in modern cities have a major impact on spatial separation, as is clearly displayed in the Bursa metropolitan area. The most favored residential districts in Bursa are Nilüfer (32.8\%), Osmangazi (22.9\%) and Yildirim (10.5\%). The planned areas in the western section of the city where Nilüfer is located and the unplanned areas in the eastern section where Yildirim is located reflect spatial differences due to socioeconomic segregation. There are physical and social inequalities between the districts. The preferred residential areas include the planned development neighborhoods in the west, while the regions of unplanned development in the east are less preferred. In the assessment of socioeconomic differentiation in neighborhoods, it was found that the district of Yildirim has multiple neighborhoods that have the lowest socio-economic scores, while Osmangazi still has neighborhoods yet to lose their prestige. The neighborhoods with the highest socioeconomic scores are present in Nilüfer. Socio-economic order points are below zero in the neighborhoods that have insufficient infrastructure, relatively limited access to public services, and a history of unplanned development, but these points increase in the neighborhoods that have planned development and housing areas for high income group. The assessment further showed that educational status and level of participation in social life were higher in the new residential areas selected by the people of the moderate- and highincome level in Nilüfer. The rates associated with these factors were relatively lower in the east of the city, in most sections of Yildirim and in the unplanned parts of Osmangazi (Mutlu \& Varol, 2017). The highest development level is present in Nilüfer according to the report prepared by the Ministry, which affects users' socio-economic status as well as their preferences, orientation and lifestyles.

\subsection{Sample and data collection}

The universe of the survey was the inhabitants of Osmangazi, Nilüfer and Yildirim in Bursa. Stratified sampling was used to reach the districts and neighborhoods. The data were collected from 500 participants in 30 neighborhoods: 11 in Osmangazi, 9 in Nilüfer and 10 in Yildirim. The participants were interviewed face-to-face using a questionnaire prepared by the author and tablet software. The questionnaire has two parts, one concerning the demographic characteristics of the participants. The other part has 25 questions about lifestyles before and during the pandemic, housing characteristics and adapting the housing to changing needs.

All the questionnaire responses were counted as percentages and frequencies. One-way analysis of variance was used to compare the number of home occupants and the responses. The chi-squared test was used to examine the relationships among the responses regarding the type of housing and district of residence. For the chi-squared test, the groups with few participants were combined with other groups and then included in the analysis. The confidence interval was $95 \%$ and $\mathrm{p}$ values of $<0.05$ were considered significant. The analyses were done using SPSS 25.0.

\section{Results}

The data obtained as a result of the analyses are examined under the two categories of objective and subjective data. 
Table 2 Demographic information

\begin{tabular}{|c|c|c|c|}
\hline & & $\mathrm{f}$ & $\%$ \\
\hline \multirow[t]{7}{*}{ Age } & $18-24$ & 88 & 17.6 \\
\hline & $25-34$ & 129 & 25.8 \\
\hline & $35-44$ & 111 & 22.2 \\
\hline & $45-54$ & 88 & 17.6 \\
\hline & $55-64$ & 49 & 9.8 \\
\hline & 65 or older & 35 & 7.0 \\
\hline & Total & 500 & 100.0 \\
\hline \multirow[t]{8}{*}{ Education level } & None & 10 & 2.0 \\
\hline & Primary school & 161 & 32.2 \\
\hline & Middle school & 79 & 15.8 \\
\hline & High school & 141 & 28.2 \\
\hline & Associate's degree & 31 & 6.2 \\
\hline & Bachelor's degree & 75 & 15.0 \\
\hline & Master's degree & 3 & 0.6 \\
\hline & Total & 500 & 100.0 \\
\hline \multirow[t]{8}{*}{ Monthly household income } & Less than $1,500 \mathrm{TL}$ & 11 & 2.2 \\
\hline & $1,500-2,500 \mathrm{TL}$ & 158 & 31.6 \\
\hline & $2,500-4,000 \mathrm{TL}$ & 78 & 15.6 \\
\hline & $4,000-5,000 \mathrm{TL}$ & 127 & 25.4 \\
\hline & $5,000-10,000 \mathrm{TL}$ & 33 & 6.6 \\
\hline & $10,000 \mathrm{TL}$ or more & 87 & 17.4 \\
\hline & No answer & 6 & 1.2 \\
\hline & Total & 500 & 100.0 \\
\hline \multirow[t]{3}{*}{ Gender } & Female & 251 & 50.2 \\
\hline & Male & 249 & 49.8 \\
\hline & Total & 500 & 100.0 \\
\hline \multirow[t]{4}{*}{ District } & Osmangazi & 220 & 44.0 \\
\hline & Yildirim & 163 & 32.6 \\
\hline & Nilüfer & 117 & 23.4 \\
\hline & Total & 500 & 100.0 \\
\hline \multirow[t]{7}{*}{ Employment } & Officer & 11 & 2.2 \\
\hline & Worker & 158 & 31.6 \\
\hline & Retired & 78 & 15.6 \\
\hline & Housewife & 127 & 254 \\
\hline & Unemployed & 33 & 6.6 \\
\hline & Self-employed & 87 & 17.4 \\
\hline & Total & 500 & 100.0 \\
\hline \multicolumn{2}{|c|}{65 or older and living with younger people } & 9 & 1.8 \\
\hline
\end{tabular}

Objective data The objective data obtained through frequency analysis include the socio-demographic characteristics of the sample (Table 2 and Table 3), the characteristics of housing (Table 4) in the neighborhood (Table 5), the conveniences offered by the neighborhood to maintain social distancing (Table 6), and information related to 
Table 3 Number of households by district

\begin{tabular}{|c|c|c|c|c|c|c|c|}
\hline Variable & District & $\mathrm{N}$ & Mean & $\mathrm{Sd}$ & $\mathrm{F}$ & $\mathrm{p}$ & Tukey \\
\hline \multirow{3}{*}{$\begin{array}{l}\text { Number of house- } \\
\text { holds }\end{array}$} & Osmangazi $\mathrm{i}^{\mathrm{a}}$ & 220 & 3,39 & 1,35 & \multirow[t]{3}{*}{6,10} & \multirow[t]{3}{*}{0,00} & \\
\hline & Yildirim $^{\mathrm{b}}$ & 163 & 3,78 & 1,47 & & & $\begin{array}{l}\mathrm{b}>\mathrm{a} \text { (Number of households } \\
\text { in Y1ldırım is higher than in } \\
\text { Osmangazi) }\end{array}$ \\
\hline & Nilüfer $^{c}$ & 117 & 3,24 & 1,33 & & & $\begin{array}{l}\mathrm{b}>\mathrm{c} \text { (Number of households } \\
\text { in Yildırım is higher than in } \\
\text { Nilüfer) }\end{array}$ \\
\hline
\end{tabular}

Table 4 Characteristics of the house

\begin{tabular}{|c|c|c|c|}
\hline & & $\mathrm{f}$ & $\%$ \\
\hline \multirow[t]{3}{*}{ Type } & Single-family home & 125 & 25.0 \\
\hline & Apartment & 311 & 62.2 \\
\hline & Housing development & 64 & 12.8 \\
\hline \multirow[t]{3}{*}{ Size $\left(\mathrm{m}^{2}\right)$} & $100 \mathrm{~m}^{2}$ or less & 202 & 40.4 \\
\hline & $100-121 \mathrm{~m}^{2}$ & 155 & 31.0 \\
\hline & $121 \mathrm{~m}^{2}$ or more & 143 & 28.6 \\
\hline \multirow[t]{6}{*}{ Rooms (bedrooms + living room) } & $1+1$ & 7 & 1.4 \\
\hline & $2+1$ & 169 & 33.8 \\
\hline & $3+1$ & 276 & 55.2 \\
\hline & $4+1$ & 35 & 7.0 \\
\hline & $5+1$ & 4 & 0.8 \\
\hline & More & 9 & 1.8 \\
\hline \multirow[t]{3}{*}{ Do you have a balcony or a patio? } & Balcony & 431 & 86.2 \\
\hline & Patio & 29 & 5.8 \\
\hline & Neither & 54 & 10.8 \\
\hline \multirow{2}{*}{$\begin{array}{l}\text { Do you have a washroom at the entrance of } \\
\text { your home? }\end{array}$} & Yes & 196 & 39.2 \\
\hline & No & 304 & 60.8 \\
\hline
\end{tabular}

Table 5 Characteristics of the neighborhood

\begin{tabular}{lccc}
\hline $\begin{array}{l}\text { Do you have recreational areas, walking paths, green spaces or open } \\
\text { areas in or around your home? }\end{array}$ & Yes & 307 & 61.4 \\
& No & 193 & 38.6 \\
\hline
\end{tabular}

Table 6 The convenience offered by the neighborhood to maintain social distance

\begin{tabular}{llll}
\hline & & $\mathrm{f}$ & $\%$ \\
\hline $\begin{array}{l}\text { Is it possible to maintain social distancing while walking } \\
\text { on the street in your neighborhood? }\end{array}$ & Yes & 345 & 69.0 \\
& No & 63 & 12.6 \\
& Sometimes & 92 & 18.4 \\
& Total & 500 & 100.0 \\
\hline
\end{tabular}


Table 7 Information about distance learning after the pandemic

\begin{tabular}{llll}
\hline $\begin{array}{l}\text { Is there a distance learning stu- } \\
\text { dent or a remote worker in your } \\
\text { household? }\end{array}$ & No & 271 & 54.2 \\
& Yes & 229 & 45.8 \\
& Total & 500 & 100.0 \\
\hline $\begin{array}{l}\text { Do you have a room for distance } \\
\text { education students or online } \\
\text { remote workers? }\end{array}$ & No & 256 & 94.5 \\
& Yes & 15 & 5.5 \\
\hline
\end{tabular}

Table 8 Lifestyle changes during \& after the pandemic

\begin{tabular}{|c|c|c|c|c|c|}
\hline Lifestyle changes & & Made & Not made & Considered & No response \\
\hline \multirow[t]{2}{*}{ Moving } & $\mathrm{f}$ & 12 & 457 & 31 & - \\
\hline & $\%$ & 2.4 & 91.4 & 6.2 & - \\
\hline \multirow[t]{2}{*}{ Changing my physical exercise habits } & $\mathrm{f}$ & 114 & 350 & 34 & 2 \\
\hline & $\%$ & 22.8 & 70.0 & 6.8 & 0.4 \\
\hline \multirow[t]{2}{*}{ Changing my shopping habits } & $\mathrm{f}$ & 239 & 234 & 26 & 1 \\
\hline & $\%$ & 47.8 & 46.8 & 5.2 & 0.2 \\
\hline \multirow[t]{2}{*}{ Changing my travel habits } & $\mathrm{f}$ & 277 & 204 & 18 & 1 \\
\hline & $\%$ & 55.4 & 40.8 & 3.6 & 0.2 \\
\hline \multirow[t]{2}{*}{ Changing my transportation habits } & $\mathrm{f}$ & 291 & 194 & 15 & - \\
\hline & $\%$ & 58.2 & 38.8 & 3.0 & - \\
\hline \multirow[t]{2}{*}{ Changing my hygiene habits } & $\mathrm{f}$ & 441 & 48 & 11 & - \\
\hline & $\%$ & 88.2 & 9.6 & 2.2 & - \\
\hline \multirow{2}{*}{$\begin{array}{l}\text { Reducing the frequency of my contact with relatives } \\
\text { other than my immediate family }\end{array}$} & $\mathrm{f}$ & 399 & 78 & 22 & 1 \\
\hline & $\%$ & 79.8 & 15.6 & 4.4 & 0.2 \\
\hline \multirow{2}{*}{$\begin{array}{l}\text { Reducing the frequency of my contact with neighbors } \\
\text { and friends }\end{array}$} & $\mathrm{f}$ & 402 & 79 & 19 & - \\
\hline & $\%$ & 80.4 & 15.8 & 3.8 & - \\
\hline
\end{tabular}

Table 9 Use of balconies, patios in the house and open areas in the neighborhood

\begin{tabular}{llll}
\hline & f & $\%$ \\
\hline How much do you use your balcony or patio each day? & Less than $1 \mathrm{~h}$ & 159 & 35.7 \\
& $1-2 \mathrm{~h}$ & 167 & 37.4 \\
& $3-4 \mathrm{~h}$ & 72 & 16.1 \\
& $5-6 \mathrm{~h}$ & 28 & 6.3 \\
& More than 6h & 20 & 4.5 \\
Did you use the open areas around your house before the pandemic? & Total & 446 & 100.0 \\
Have you been using the open areas around your house during the pandemic? & Yes & 192 & 62.5 \\
& No & 115 & 37.5 \\
& No & 128 & 41.7 \\
& Total & 307 & 100.0
\end{tabular}


distance learning in terms of the residents and housing (Table 7). Variance analysis was conducted to determine the number of households per district (Table 2).

Subjective data The subjective data obtained through frequency analysis include the lifestyle changes during the pandemic, including physical exercise, shopping, travel, transportation, hygiene habits, and contact with relatives, neighbors and friends (Table 8), the use of balconies, patios and open spaces in the housing and neighborhood (Table 9), the changing behaviors regarding hosting visitors and airing out clothes and

Table 10 Changing behaviors regarding hosting visitors and airing out clothes and packages after the pandemic

\begin{tabular}{llll}
\hline & f & $\%$ & \\
\hline Where do you host visitors? & Balcony & 20 & 4.0 \\
& Patio & 9 & 1.8 \\
& Yard & 4 & 0.8 \\
& Living room & 366 & 73.2 \\
& No visitors & 101 & 20.2 \\
& Total & 271 & 100.0 \\
Clothing, Packages And Groceries & & & \\
Do you air out clothing, packages & Yes & 443 & 88.6 \\
and groceries? & & & \\
& No & 57 & 11.4 \\
& Total & 500 & 100.0 \\
Where do you air them out? & Outside the door & 47 & 10.6 \\
& Balcony or patio & 372 & 84.0 \\
& At the entrance & 15 & 3.4 \\
& Yard & 9 & 2.0 \\
& Total & 443 & 100.0 \\
\hline
\end{tabular}

Table 11 Behaviors of the residents regarding social distancing and personal hygiene in the neighborhood

\begin{tabular}{llll}
\hline $\begin{array}{l}\text { Do the residents of your neighborhood pay attention to social } \\
\text { distancing, washing and wearing masks? }\end{array}$ & Yes & 336 & 67.2 \\
& No & 62 & 12.4 \\
& Sometimes & 102 & 20.4 \\
& Total & 500 & 100.0 \\
\hline
\end{tabular}

Table 12 Changing Personal Hygiene Habits by District

\begin{tabular}{|c|c|c|c|c|c|c|}
\hline & & \multicolumn{3}{|l|}{ District } & \multirow[t]{2}{*}{$X^{2}$} & \multirow[t]{2}{*}{$p$} \\
\hline & & Osmangazi & Yildirim & Nilüfer & & \\
\hline \multicolumn{7}{|c|}{ Changing my hygiene habits } \\
\hline \multirow[t]{2}{*}{ Increased } & $\mathrm{f}$ & 209 & 154 & 78 & 46.33 & 0.00 \\
\hline & $\%$ & 95.4 & 94.5 & 72.9 & & \\
\hline \multirow[t]{2}{*}{ Did not change } & $\mathrm{f}$ & 10 & 9 & 29 & & \\
\hline & $\%$ & 4.6 & 5.5 & 27.1 & & \\
\hline \multirow[t]{2}{*}{ Total } & $\mathrm{f}$ & 219 & 163 & 107 & & \\
\hline & $\%$ & 100.0 & 100.0 & 100.0 & & \\
\hline
\end{tabular}


Table 13 Attention to COVID-19 Precautions and Social Distancing by District

\begin{tabular}{|c|c|c|c|c|c|c|c|}
\hline & & & District & & & $X^{2}$ & $p$ \\
\hline & & & Osmangazi & Yildirim & Nilüfer & & \\
\hline Is it possible to maintain social & Yes & $\mathrm{f}$ & 118 & 112 & 115 & 88.01 & 0.00 \\
\hline distancing while walking on the & & $\%$ & 53.6 & 68.7 & 98.3 & & \\
\hline & No & $\mathrm{f}$ & 30 & 31 & 2 & & \\
\hline & & $\%$ & 13.6 & 19.0 & 1.7 & & \\
\hline & Sometimes & $\mathrm{f}$ & 72 & 20 & 0 & & \\
\hline & & $\%$ & 32.7 & 12.3 & 0.0 & & \\
\hline Are the residents of your neighbor- & Yes & $\mathrm{f}$ & 113 & 116 & 107 & 64.10 & 0.00 \\
\hline hood careful about COVID-19 & & $\%$ & 51.4 & 71.2 & 91.5 & & \\
\hline $\begin{array}{l}\text { precautions as social distancing, } \\
\text { washing and wearing masks? }\end{array}$ & No & $\mathrm{f}$ & 34 & 25 & 3 & & \\
\hline & & $\%$ & 15.5 & 15.3 & 2.6 & & \\
\hline & Sometimes & $\mathrm{f}$ & 73 & 22 & 7 & & \\
\hline & & $\%$ & 33.2 & 13.5 & 6.0 & & \\
\hline
\end{tabular}

packages (Table 10), and the behaviors of the residents regarding social distancing and personal hygiene (Table 11).

The data obtained from the chi-squared test performed within the scope of the subjective data concerning behaviors related to the residential environment addressed the changing hygiene and social distancing behaviors by district (Tables 12,13), the behaviors related to housing type and the use of green spaces (Table 14), and the relationship between district and physical exercise (Table 15).

\subsection{Objective data}

The participants' ages were: 18-24 (7.6\%), 25-34 (28.8\%), 35-44 (22\%), 45-54 (17.6\%), $55-64(9.8 \%)$ and 65 or older (7\%). Their education levels were: no education (2\%), primary school (32.2\%), middle school (15.8\%), high school $(28.2 \%)$, associate's degree $(6.2 \%)$, undergraduate degree (15\%) and graduate degrees $(0.6 \%)$. Their monthly household incomes were: 1,500-2,500 TL (31.6\%) and 4,000-5,000 TL (25.4\%). Of the participants, $50.2 \%$ were female, and $49.8 \%$ were male. The sample included $44 \%$ Osmangazi residents, $32.6 \%$ Yildirim residents and $23.4 \%$ Nilüfer residents. Of the participants, $31.6 \%$ were workers, $25.4 \%$ were housewives, $17.4 \%$ were self-employed, and $15.6 \%$ were retired (Table 2).

Table 3 shows that the number of people living in the house significantly differed by district, as understood from the one-way analysis of variance $(p<0.05)$. The mean number of individuals living in a house in Yildirim is higher than that of those living in a house in Osmangazi and in Nilüfer.

Of the participants, $25 \%$ live in single-family homes, $62.2 \%$ live in apartments, and $12.8 \%$ live in housing developments. The size of the homes of $40.4 \%$ are $100 \mathrm{~m}^{2}$ or less, $31 \%$ live in homes with areas of $100-121 \mathrm{~m}^{2}$, and $28.6 \%$ live in homes with areas of 121 $\mathrm{m}^{2}$ or more. Most of the participants live in $2+1(33.8 \%)$ or $3+1(55.2 \%)$ houses. Of the participants, $86.2 \%$ have balconies, $5.8 \%$ have patios, and $10.8 \%$ have neither. Moreover, 


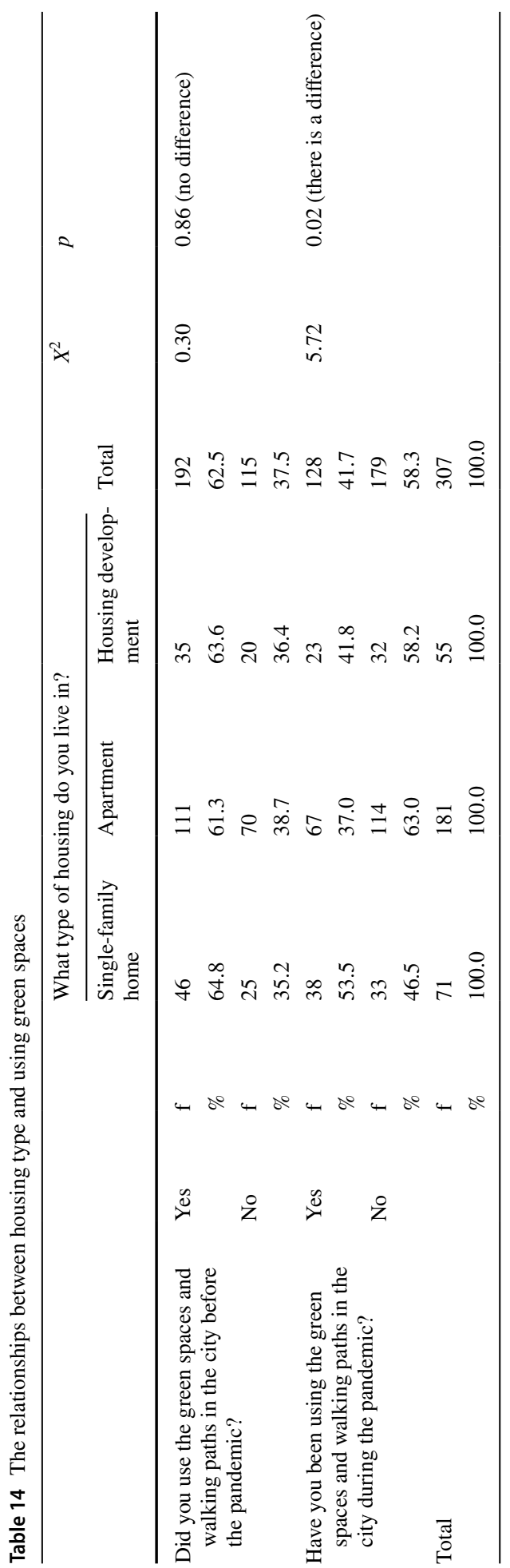


Table 15 The relationships between district and physical exercise

\begin{tabular}{|c|c|c|c|c|c|c|}
\hline & & \multicolumn{3}{|l|}{ District } & \multirow[t]{2}{*}{$X^{2}$} & \multirow[t]{2}{*}{$p$} \\
\hline & & Osmangazi & Yildirim & Nilüfer & & \\
\hline \multicolumn{7}{|c|}{$\begin{array}{l}\text { Have your physical exercise habits changed during the pan- } \\
\text { demic? }\end{array}$} \\
\hline \multirow[t]{2}{*}{ Yes } & f & 59 & 27 & 28 & 7.52 & 0.02 \\
\hline & $\%$ & 28.5 & 17.0 & 28.6 & & \\
\hline \multirow[t]{2}{*}{ No } & $\mathrm{f}$ & 148 & 132 & 70 & & \\
\hline & $\%$ & 71.5 & 83.0 & 71.4 & & \\
\hline \multirow[t]{2}{*}{ Total } & $\mathrm{f}$ & 207 & 159 & 98 & & \\
\hline & $\%$ & 100.0 & 100.0 & 100.0 & & \\
\hline
\end{tabular}

$39.2 \%$ of the participants have a washroom where they can wash their hands at the entrance of their home, while $60.8 \%$ do not have this (Table 4).

According to the frequency analysis, of the participants, $61.4 \%$ have recreational areas, walking paths, green spaces or open areas in or around their homes (Table 5).

Table 6 shows that $69 \%$ of the participants reported that they could maintain social distancing while walking in their neighborhood, $12.6 \%$ said that they could not, and $18.4 \%$ reported that they could do so sometimes.

According to the frequency analysis, 54.2\% have household members who are distance education students or who work remotely, and $94.5 \%$ have a separate room where they can work in isolation (Table 7).

\subsection{Subjective data}

During the pandemic, the majority of participants did not move (91.4\%), but $6.2 \%$ considered doing so. Of the participants, $47.8 \%$ said that their shopping habits changed, $58.2 \%$ said that their transportation habits changed, and $88.2 \%$ said that their hygiene practices changed. Of the participants, $79.8 \%$ reduced the frequency of their contact with relatives other than their immediate family, $80.4 \%$ reduced the frequency of their contact with neighbors and friends (Table 8).

Of the participants, 35.7\% said that they use their balconies or patios for less than $1 \mathrm{~h}$, $37.4 \%$ said that they use them for $1-2 \mathrm{~h}, 16.1 \%$ said that they use them for $3-4 \mathrm{~h}, 6.3 \%$ said that they use them for 5-6h, and $4.5 \%$ said that they use for more than $6 \mathrm{~h}$. Of the participants, $62.5 \%$ said that they used facilities such as walking paths, green spaces, open areas and playgrounds before the pandemic, and $41.7 \%$ said that they did so during the pandemic (Table 9).

Of the participants, $20.2 \%$ said that they had no visitors during the pandemic, $4 \%$ hosted visitors on their balconies, $1.8 \%$ hosted them on their patios, $0.8 \%$ hosted them in their yards, and $73.2 \%$ hosted them in their living rooms. Of the participants, $88.6 \%$ of them have been airing out their clothing, packages and groceries during the pandemic: $10.6 \%$ outside the door, $84 \%$ on the balcony or patio, $3.4 \%$ in the entrance hall and $2 \%$ in the yard (Table 10).

According to the frequency analysis, $67.2 \%$ of the participants reported that they are careful about social distancing and personal hygiene (washing and wearing masks), and $12.4 \%$ did not respond (Table 11). 
Table 12 shows that $95.4 \%$ of the participants residing in Osmangazi, $94.5 \%$ of the participants residing in Yildirim, and $72.9 \%$ of the participants residing in Nilüfer stated that their personal hygiene practices had changed during the pandemic. The relationship between the district hosting the place of residence and personal hygiene practices was significant $(p<0.05)$, with rate of change and increase regarding the habits of personal hygiene among the participants residing in Osmangazi and Yildirim being higher than the rates observed among the participants residing in Nilüfer.

Based on the data obtained from the chi-squared test, as shown in Table 13, there is a significant relationship between district of residence and maintaining social distancing in the neighborhood $(p<0.05)$. Of the Nilüfer residents, $98.3 \%$ said that it is possible to maintain social distancing while walking on the street in their neighborhood, $68.7 \%$ of the Yildirim residents and $53.6 \%$ of the Osmangazi residents said that it is possible to maintain social distancing while walking on the street in their neighborhood. The percentage of affirmative responses in Nilüfer was significantly higher than it was in the other two districts (Table 13).

According to the results of the chi-squared test, as shown in Table 13, there is a significant relationship between district of residence and carefulness about social distancing, washing, and wearing masks $(p<0.05)$. Of the Nilüfer residents, $91.5 \%$ said that they pay attention to COVID-19 precautions (social distancing, washing and using masks), and $71.2 \%$ of the Yildirim residents and $51.4 \%$ of the Osmangazi residents said that they pay attention to social distancing, washing and using masks. The percentage of affirmative responses was highest in Nilüfer and lowest in Osmangazi (Table 13).

The data obtained from the chi-squared test shows that there are no significant differences in the use of green spaces and walking paths by housing type before the pandemic $(p>0.05)$, but there are differences during the pandemic $(p<0.05)$. Single-family home occupants used green spaces and walking paths more $(53.5 \%)$ than that of apartment dwellers (37\%) and the residents of housing developments (41.8\%) during the pandemic (Table 14).

There is a significant relationship between district of residence and changes to physical exercise habits according to the chi-squared analysis $(p<0.05)$. Of the Osmangazi residents, $28.5 \%$ reported that their physical exercise habits changed during the pandemic, and $17 \%$ of the Yildirim residents and $28.6 \%$ of the Nilüfer residents reported that their physical exercise habits changed during the pandemic. There were more affirmative responses in Osmangazi and Nilüfer districts than in Yildirim (Table 15).

The data presented in the fifth section are discussed in the Discussion section in line with the lifestyles that changed after the pandemic, and the differences between the districts are interpreted in relation to the changes determined in the pre- and post-pandemic period. The interpretation of data as well as the relevant results obtained from different research studies found in the literature review support the evaluation of the data obtained in Bursa.

\section{Discussion}

In this section, the changes observed in line with the purposes, the pandemic and behaviors and their relationships with the characteristics of the housing and housing environment are discussed and collectively assessed by comparing them with the results found in research studies from the relevant literature. This study's results show that Bursa 
residents' lifestyles and habits changed considerably during the pandemic. They reduced their use of the amenities in the city and started using those around their homes, and they adapted their housing to their pandemic lifestyles. However, access to housing, the use of housing, residential environments and urban facilities varied by district. Almost all of Bursa's residents changed their hygiene habits during the pandemic. The rate of change observed in the habits of hygiene practices among the participants residing in Osmangazi and Yildirim was higher than the rate observed among the participants residing in Nilüfer, which can be attributed to the respective socioeconomic status, lifestyle and COVID-19 measures of these districts.

Most of the participants stopped using public transport, and half of them changed their shopping habits. As in other countries subject to strict lockdowns, shopping behaviors have changed in Turkey as well, leading people to buy necessity goods and shop online (Eger et al., 2021; Çakiroğlu et al., 2020; Kayabaşi, 2020; Demirdöğmez et al., 2020). COVID-19 also made it necessary to increase the numbers of shopping units for basic needs within walking distance in Bursa. Increased transportation by foot was a result of hygiene practices and less use of public transport. These behaviors vary by districts and living conditions.

The majority of this study's participants live in apartments with 2 or 3 bedrooms. Garber (2020) noted that the number of rooms became more significant during the pandemic. This housing type is suitable for the lifestyle of families with one or two children. During the pandemic, distance education became another important factor in the lifestyles of families. Distance education is now widespread around the world (Chen et al., 2020; Sindiani et al., 2020). Distance education at home causes discomfort for both children and parents, which affects academic success (Al Lily et al., 2020; Bayrakdar \& Guveli, 2020; Brom et al., 2020). In Bursa, more than half of the households have members who are engaged in distance education or remote work. Three-room homes, where approximately half of the residents live, better for them. More flexible use of two-room homes to meet the needs of residents in different age groups will increase their efficiency. Online education and work require at least one room for use an office. In the present study conducted in Bursa, $90 \%$ of the participants lived in two or threeroom homes, and there was no difference found between the districts regarding this data. The absence of flexible housing in any of the regions, as determined from the study results and observations, means that flexible use housing must be a priority in the "new normal". However, the households in Yildirim are more densely populated compared to that of other districts, which is related to the higher number of children, higher number of migrants and relatively lower income level in Yildirim. These factors were responsible for the faster spread and frequency of the disease in the district, which hosts a large number of blue-collar workers who use mass transportation more often. With online education/working processes becoming a normal part of the life, it is essential that room designs be flexible enough for use as workspaces. More than one occupant may be engaged in distance education or remote work, making the transformation of more than one space into a work area important. Due to the pandemic, interiors require workplaces, children's play areas and places for elderly assistance, as a variety of studies have emphasized (Amerio et al., 2020; Capolongo et al., 2020; D'Alessandro et al., 2020). Flexible and shareable housing that accommodates social distancing can satisfy the changing needs of residents. Flexible designs with partition panels that allow the space to be used by different members of the family without causing mutual discomfort, as well as modular surfaces that residents can manage have gained importance not only for the quality of housing, but also for COVID-19 quality of life. 
Another requirement for flexible use is that people 65 can live with other households. They and other at-risk groups should not stay in spaces with poor ventilation during the COVID-19 pandemic (https://www.cdc.gov/coronavirus/2019-ncov/need-extra-preca utions/older-adults.html). For them, even breathing in such a house can be dangerous. If these people need care, it should be ensured that, along with an isolated room, they should have separate washrooms and kitchens. The flexibility of the housing space in the new lifestyle has become quite necessary for distance education, work area, sharing of $65+$ and $0-5$ age groups in need of care.

Almost $40 \%$ of the households in Bursa reported that they have a washroom at the entrance to their homes. One important way to prevent the spread of this disease is careful hygiene, including handwashing before touching anything or anyone in the home. It is a problem that over $60 \%$ of the participants do not have a washroom by their entrances. Regarding this specific datum, no significant difference was found by districts. Although it is estimated that the district of Nilüfer which is more developed in terms of planning has houses with a WC or washroom in the entrance, the data indicate that the district had similar numbers to that of the entire city of Bursa. While such washrooms were a good design choice before the pandemic, they are now necessary to reduce the risk of contagion. Although Guilomoto and Licart (2020) found that low-income households in India do not have handwashing facilities, having washrooms near the entrance did not vary by income level or district in Bursa. This space is very important in residential design.

Almost all of the participants have spaces to get fresh air such as balconies and patios, and most of them use these spaces for a few hours each day. During the COVID-19 pandemic, balconies have become places of critical importance by offering fresh air to the residents of 4-5 story buildings (Megahed \& Ghoneim, 2020; Poon, 2020; Türkoğlu, 2020). Balconies also help to alleviate stress and have made it easier to express solidarity, especially in Italy through music (Calvo \& Bejarano, 2020). Balconies are a place of relaxation and escape for apartment dwellers during lockdowns and quarantines in Bursa. Making them more efficient use will increase their use time during the pandemic.

During the pandemic, most of the participants reduced their contact with relatives, neighbors and friends, and some of them entirely stopped receiving guests. Some host guests on their balconies or patios during the pandemic, but many still host guests in their living rooms. Socializing in indoor spaces with poor ventilation increases the likelihood of contagion. Due to air flow and social distancing, larger, more functional and efficient should be designed for welcoming guests. They can be useful for airing out packages. In Bursa, and in Turkey as a whole, online shopping has increased, and the virus remains infectious on surfaces for $72 \mathrm{~h}$, making packages risky (Alaimo et al., 2020; Arora et al., 2020; Hashem, 2020; Sarla, 2020). This study found that $85 \%$ of the participants air out their packages and groceries on balconies and patios, which they also use to get fresh air. Designing balconies and patios with more than one room to offer flexible use can ensure that the packages' messiness and risk are separated from balcony users. Balconies can thus be used as efficient spaces where guests can be entertained; people can socialize without leaving their homes and contact with the open air. In addition to balconies, for airing out packages outside the house and, if possible, for handwashing and changing clothing, it would be good to provide intermediate spaces between the interior and exterior, similar to the windbreak rooms in single-family homes.

Approximately $60 \%$ of the participants said that they have recreational areas or green spaces in or around their homes. Green areas integrated into the city and close to residential areas support people's health, social interaction and physical activity. A healthy, active city life should recognize the value of physical activity and offer spaces 
for physical activity, including green spaces for everyone (Edwards \& Tsouros, 2008). The fact that $40 \%$ of this study's participants have no green spaces or open areas in or around their homes is bad for the health of the city and its inhabitants. It has been proven that quarantines have long-term cardiovascular effects by combing unhealthy lifestyles, anxiety and lack of physical exercise. Healthy lifestyles are now required for health reasons (Mattioli et al., 2020; Pieh et al., 2020). The lack of qualified walking paths, green spaces, playgrounds and open areas for physical activities for almost half of the residents in Bursa's residential environments emerged as a negative factor during the COVID-19 pandemic.

The differences regarding users' attitudes are compared in terms of physical and socioeconomic dynamics, as summarized in Table 16, in the paragraph that follows this one. This study found there to be differences between the use of recreational areas, green spaces and walking paths before and during the pandemic. The homes of more than half the participants are close to recreational areas, and during the pandemic, their use of their open areas around them increased by about 20\%; however, their use of recreational areas decreased during the pandemic. Throughout the pandemic, the increased number of people engaged in distance education and remote work, the lockdowns and the avoidance of crowded areas due to social distancing led people to stay away from urban spaces and to remain in or around their homes. This situation has increased in occupational groups that have the opportunity to work remotely, especially in Nilüfer. The study further found that people living in detached houses and housing sites use recreational and green areas more than that of those living in apartments. Isolated detached houses and high-rise housing sites are more common in the zones attached to urban areas in Nilüfer. Single-family homes and housing developments are common in Nilüfer as they are preferred by people with higher incomes (Fig. 10). In the other two districts, apartment buildings are more prevalent, and there is dense traffic and fewer open areas. Nilüfer offered its high-income residents the best opportunities for physical activity during the pandemic because it has the most single-family homes or housing developments with yards, and its neighborhoods have parks and recreational areas (Fig. 11). According to observations, the district of Yildirim was the most unsuitable for the use of green area, was developed in an unplanned manner, with illegal houses, and had a dense intersection of pedestrian and vehicle circulation, but in Osmangazi, these characteristics differed by neighborhood (Fig. 12-13). Nilüfer, on the other hand, hosted the most suitable neighborhoods. Residents generally access parks, such as Botanik Park or Kültürpark, with their private vehicles or on foot, and they enjoy the green areas. Owing to the residents' behaviors, like their interaction with nature, their physical activity, and the amount of time they spend with the family, they utilized the recreational areas more. The attitudes associated with these behaviors particularly stand out in the neighborhoods of Çamlica, Beşevler, İhsaniye and Demirci, all of which are close to the urban center and host parks and open areas within the housing environment, and where people with moderate and moderate-high incomes live in detached houses and sites. These same attitudes are also really prominent in and around housing sites in Balat and 23 Nisan, which are preferred by high-income people. People who had access to green areas in their housing environments started to prefer spending time in these environments rather than in the crowded urban parks. Increased participation in social life in Nilüfer, the most developed district of Bursa, as well as higher educational status and socio-economic score supports the aforementioned finding. Like this study, other studies too have found that individual tendencies have changed. Large green spaces that facilitate socially distanced exercise and individual recreation should be included in residential environments because they support physical and mental health (Andreucci et al., 2019; Honey-Rosés et al., 2020). Studies 


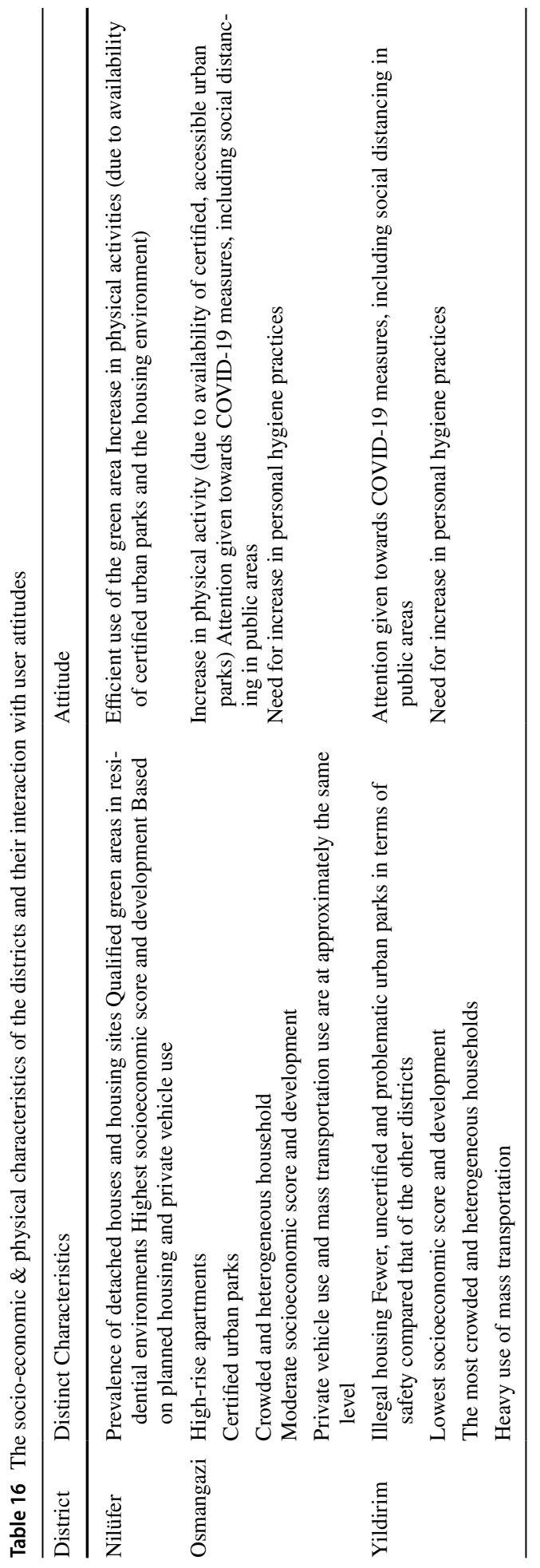



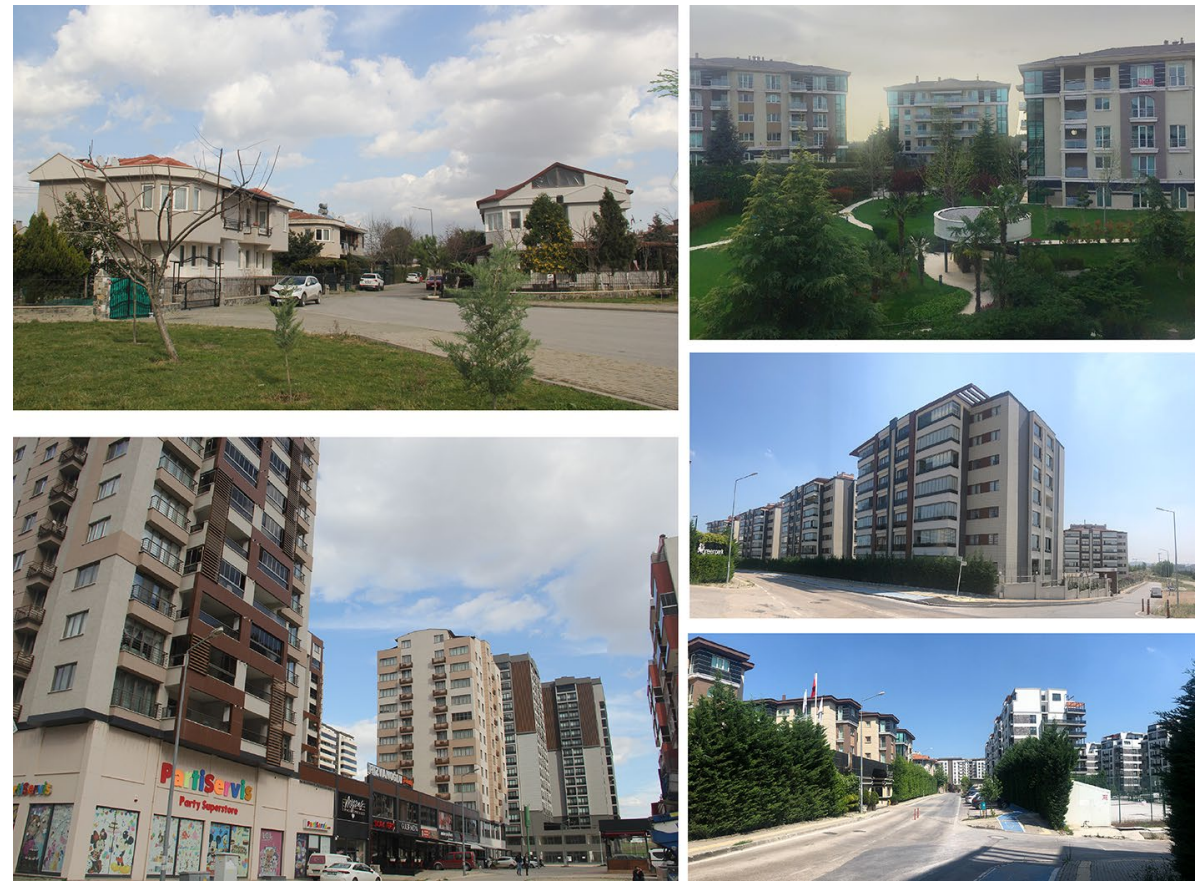

Fig. 10 Views from single-family homes and housing developments in Nilüfer
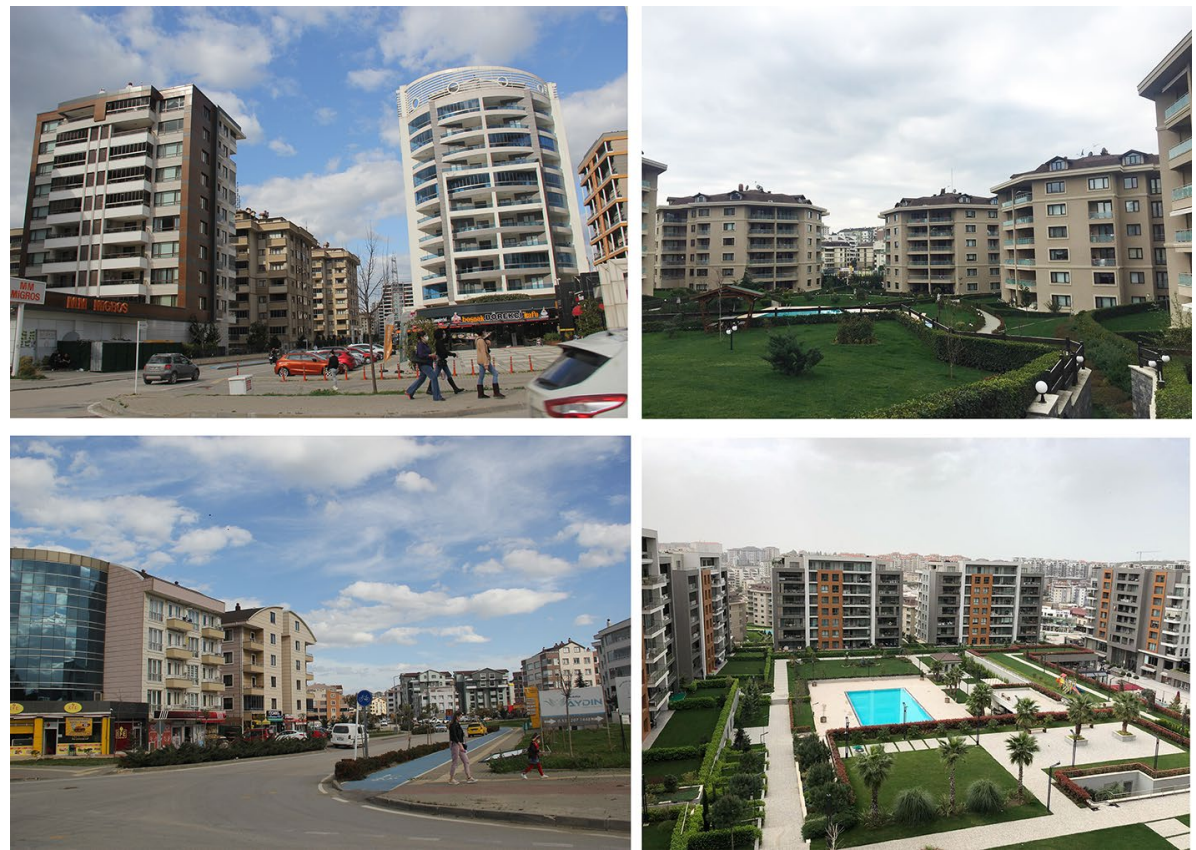

Fig. 11 Housing environments that support the use of recreational areas in Nilüfer and that are of higher quality than that of the environments in other districts 

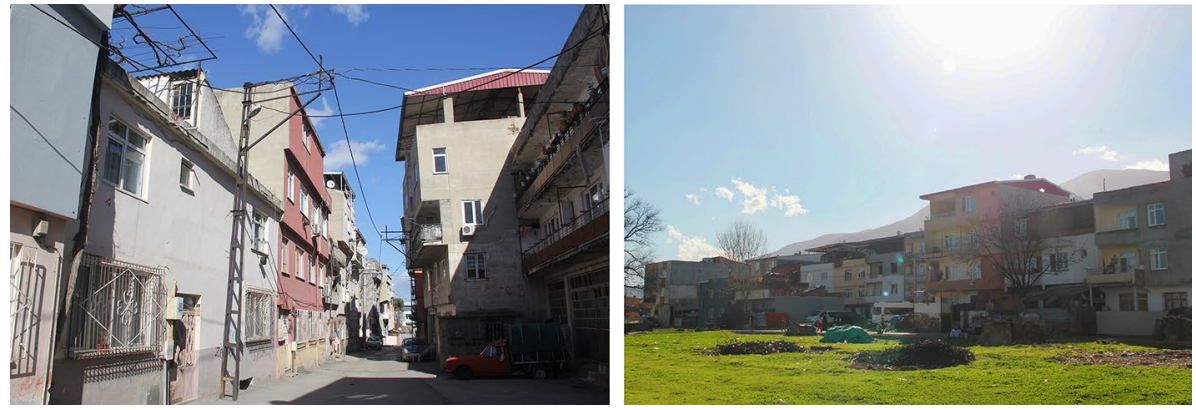

Fig. 12 The urban texture in Yildirim, which underwent unplanned housing and is low quality and lacks green areas
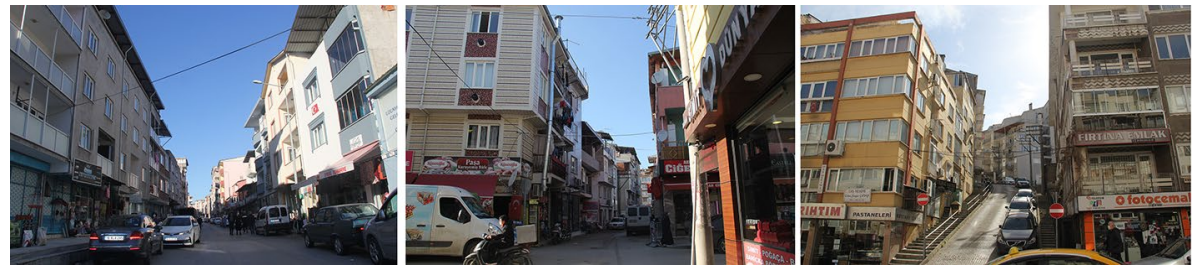

Fig. 13 The lack of green areas in the intense, heterogeneous and generally low-quality urban texture of Osmangazi

have found that people with higher incomes reside in places that offer better opportunities for physical activity (Estabrooks et al., 2006; Giles-Corti \& Donovan, 2002).

This study also examined changes in physical exercise and concluded that the physical activities of most of its participants did not change. Different countries have experienced increases and decreases in physical exercise during the pandemic (Owen et al. 2021; López-Moreno 2020; Di Renzo et al. 2020). However, when evaluated by district, the physical activities of the Osmangazi and Nilüfer residents increased more than those of the Yildirim residents. These aforementioned findings change according to (a) the availability of exercise opportunities provided by the housing environment and the housing typology, (b) the physical environment of the district, which includes green areas and parks and their availability, and (c) the lifestyle (based on socio-economic status) of the people living in the district and their awareness level. Osmangazi, a district in the urban center of Bursa, has a high concentration of high-rise concrete apartments, but the presence of urban parks that are spread across a wide area provides a great advantage. The fact that Küçükbalikli and Panayir are close to Botanik Park, that Maksem and Çekirge are only a short distance from Reşat Oyal Kültür Park, Merinos Parki and Mihrapli Park, and that Güneştepe, Hamitler and Yunuseli are near Hürriyet Ziraat Parki increases the opportunity residents have to engage in physical activity behaviors (Fig. 14). Having the ability to access farther away parks in a shorter period with a private vehicle also plays a role in this regard. In the area where Emek and Bağlarbaşi are located, there is no qualified urban park within walking distance due to the heterogeneous and unplanned settlements in Osmangazi. According to the interviews with and observations of the residents, the features of both the detached housing environments and the housing sites in Nilüfer increased the physical activity behaviors with pandemic in the neighborhoods of Balat, İhsaniye, 23 Nisan, Çamlica and 

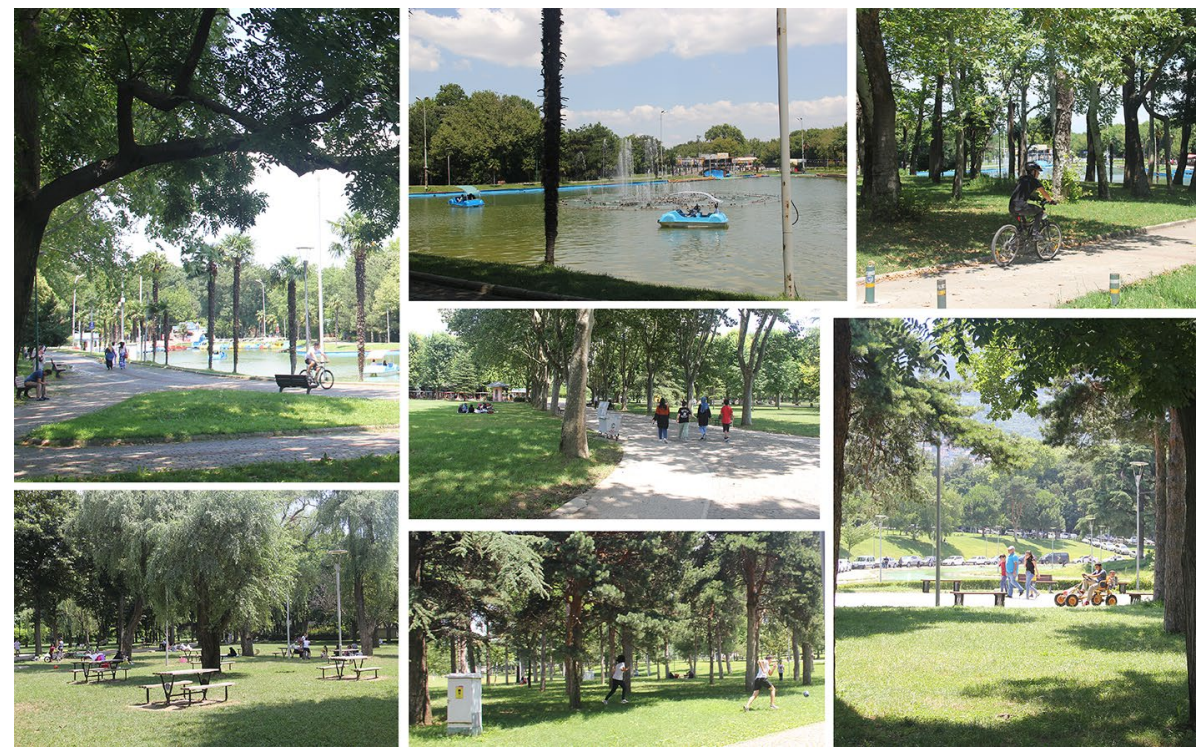

Fig. 14 The parks that increase the physical activity in Osmangazi
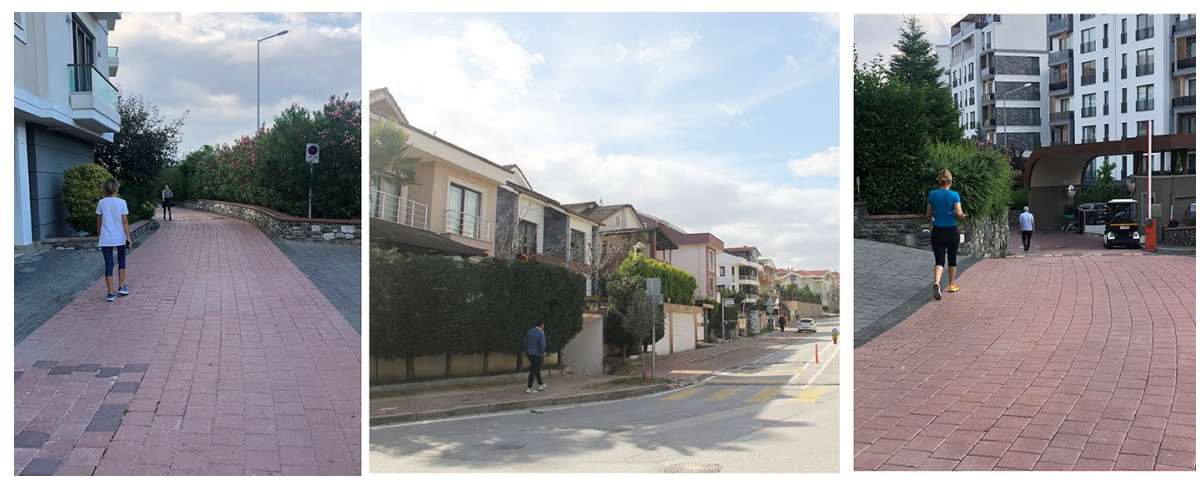

Fig. 15 Views from different housing environments that support physical activity behaviors in Nilüfer
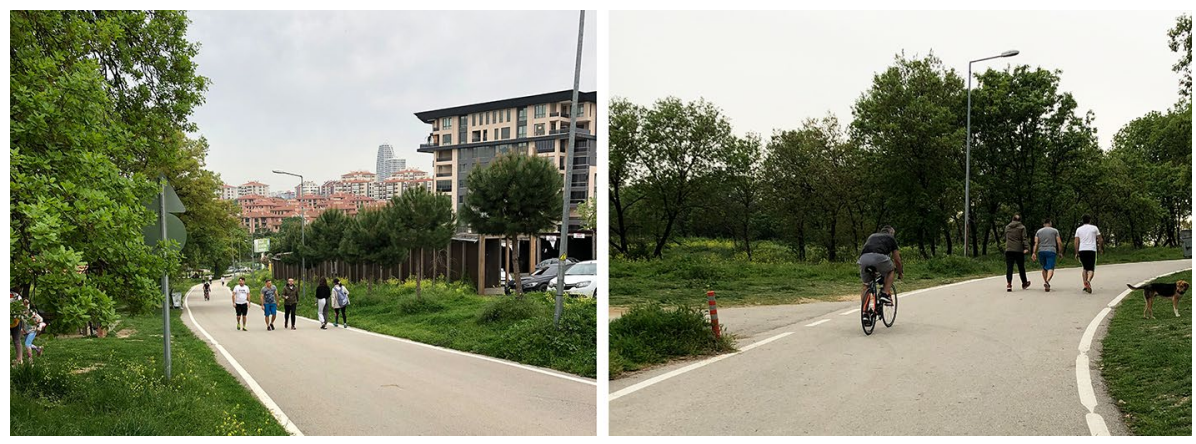

Fig. 16 Views from the urban parks in Nilüfer 

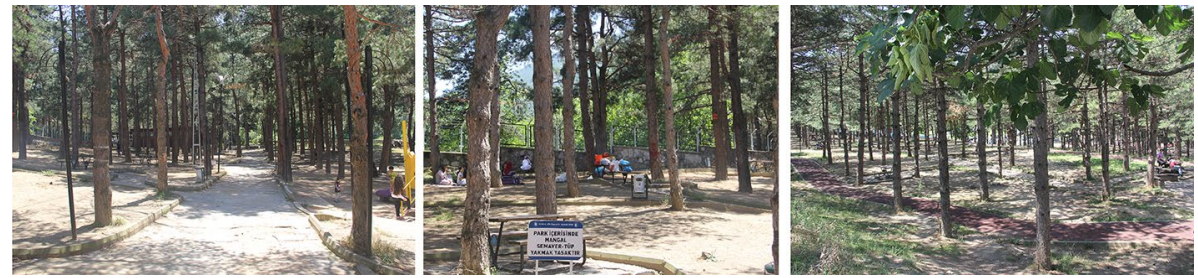

Fig. 17 Parks that are not used efficiently and are more neglected \& unqualified than other districts in Yildirim

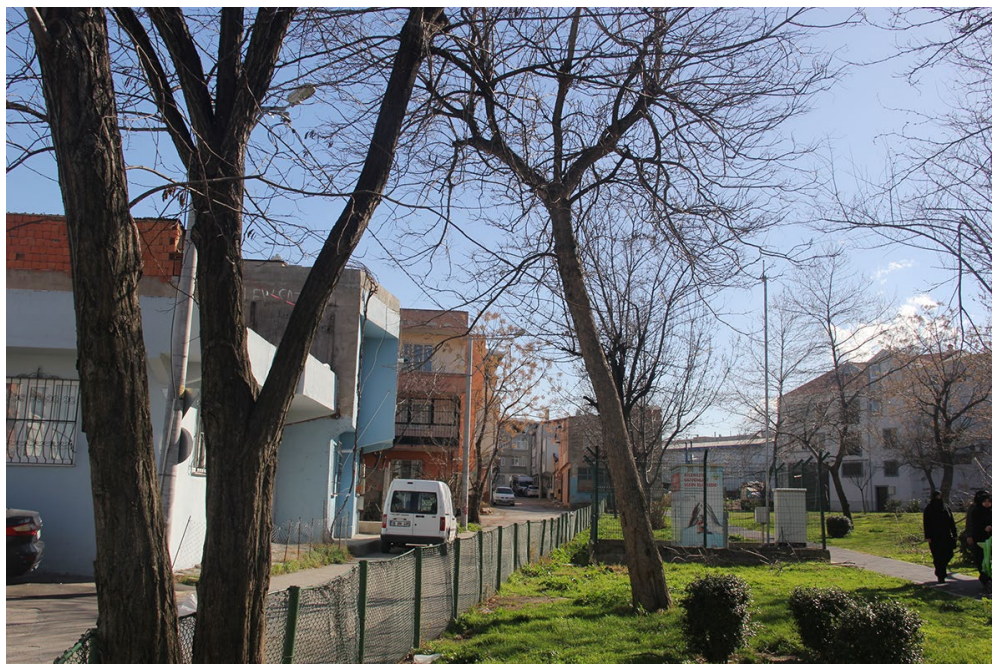

Fig. 18 A view of the uncertified green areas present in the unplanned housing environment in Yildirim

Kültür (Fig. 15-16). In a separate study conducted in Balat by the author, it was understood that the recreational areas in the housing sites satisfied residents in terms of socialization and physical activities (Gür et al. 2020). The urban areas in Beşevler and Demirci are suitable for walking, and there are qualified parks in the district within walking distance. The presence of multiple certified, safe urban parks in the district supports the physical activity attitudes. The main problem in the district of Yildirim is the absence of such parks. Yildirim hosts Temenyeri, 152 Evler, Vakif, and Sağlik Parks, but physical activity behaviors are not common in these narrow areas stuck within a dense housing texture (Fig. 17-18). The use of parks and physical activities have decreased in the district, as the residents who came to the district through migration and who have a lower income level do not feel safe in the parks in the district (Fig. 19). In addition to the interviews and observations conducted as part of the present study, it was also found in a separate research study conducted by the author that the people in the district do not feel safe (Gür \& Erbil, 2018). Furthermore, physical activity behaviors increased in Osmangazi and Nilüfer in accordance with the higher socio-economic structure. This is because highly educated people are more aware of the need for physical exercise and therefore increased their physical exercise behaviors as walking, running or cycling during the pandemic. Low-income neighborhoods are more likely to lack environments for physical activity than high-income neighborhoods. 


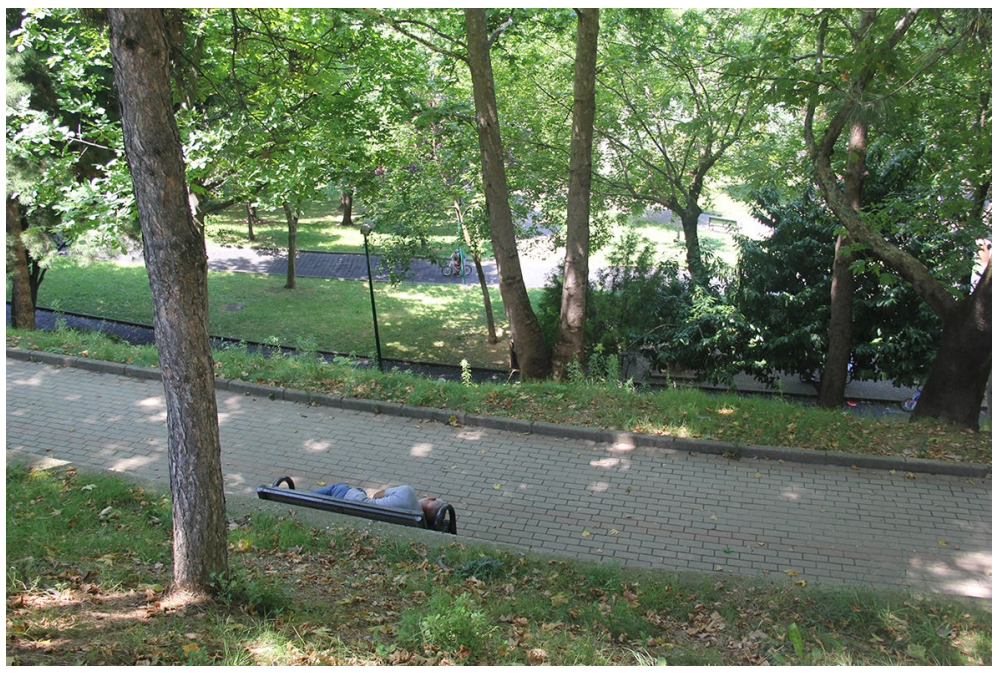

Fig. 19 A person sleeping on a park bench in Yildirim that threatens the sense of security

More physical activity, walking and vigorous exercise goes on in high-income neighborhoods (McMurray et al. 2000; Estabrooks et al. 2006). Giles-Corti and Donovan (2002) found low levels of vigorous activity because low-income residents have to walk for transportation. This study's results in Bursa are similar. Compared to the other two districts, low-income Yildirim residents have to use public transportation or walk. There is little time and few opportunities for blue-collar people in Yildirim who cannot work remotely, which makes physical activity a "luxury" for them. The higher education and income levels of Osmangazi and Nilüfer residents alter their work and living conditions, and remote work has increased in these districts during the pandemic. In parallel to the results found by Yilmaz et al. (2019) and Mutlu and Varol (2017), the highest development level was seen in Nilüfer, which reflects users' socio-economic status as well as their preferences, orientation, and lifestyles. This fact and their residential environments support their ability to engage in physical activities. The cycling routes and parks developed by the Municipality of Nilüfer also play a key role here, along with the impact of better topographical availability compared to that of other districts.

Differences were found between the districts in terms of the following: (a) hygienerelated habits, (b) residents' compliance with COVID-19 precautions (social distance, hygiene, use of mask), and (c) maintaining social distance in public areas. Change of habits regarding hygiene practices in Osmangazi and Yildirim was greater than the change implemented by the residents of Nilüfer. In other words, the residents living in Osmangazi and Yildirim increased their habits of hand hygiene, frequent mask change, frequent showering, and cleaning their spaces. Related to above-reported finding, half of the Osmangazi residents and more than one-third of the Yildirim residents said that social distancing could not be maintained on the street in their neighborhoods. In contrast, almost all the residents of Nilüfer reported that they could easily maintain social distancing on the streets in Nilüfer. A significantly higher rate of Nilüfer residents compared to that of the residents in the other districts responded in the affirmative to this question. A similar relationship was found between social distancing in public spaces and personal care precautions taken for COVID-19. While almost all the Nilüfer residents were careful about these issues, the 
Osmangazi residents cared the least about these precautions. The increase seen in personal hygiene practices by more crowded and heterogeneous households in Yildirim and Osmangazi can be attributed to the apprehensiveness these households have about the people who use the public areas, the less attention they believe these people give to COVID-19 measures, and the difficulty in adhering to social distancing rules. In Nilüfer, people feel safer because there is a greater tendency that people comply with the preventive measure when using the public areas and because they attributed importance to their personal hygiene even before the disease. The results correspond to the varying socio-economic level and development level of the districts. The personal hygiene of the people with lower income status were at the minimum level in the pre-pandemic period, and public areas are generally dirtier and more neglected in areas of low socio-economic status and low development levels (Fig. 17). Therefore, more attention was paid to hygiene in these districts during the post-pandemic period.

The more frequent use of mass transportation in Osmangazi and Yildirim, along with the lower socio-economic status and intensive use of spaces within the dense texture of these districts make social distancing more challenging, and therefore, the desire to protect oneself from the disease increases the attention given to personal hygiene. Yildirim and Osmangazi are shown in red on the risk map of Bursa from December 2020, indicating greater risk and number of cases and thereby proving that COVID-19 measures and social distancing rules are not being sufficiently observed in these districts (Fig. 20). In Nilüfer, where people with higher socio-economic and educational status live, there is greater awareness of preventive measures and compliance with practices in public areas and support for less use of public areas. As higher financial status is related to higher rate of use of private vehicles in the city instead of mass transportation, the personal hygiene practices of the residents in this district before the pandemic remained the same as it did during the pandemic. Studies have found that awareness levels increase with education, and increased awareness leads to more careful social distancing, hygiene and mask-wearing (Alahdal et al., 2020; Nooh et al., 2020; Sadiq et al., 2020; Wise et al., 2020; Zegarra-Valdivia et al., 2020). More educated, high-income groups can work remotely, which allows them to be more careful, but people in densely populated and poor areas are more vulnerable to disease (Baker et al., 2020; Głąbska et al., 2020; Jones \& Grigsby-Toussaint, 2020; Weill et al., 2020). Nilüfer's residents have higher education levels and are both more aware and more careful about following the pandemic precautions. Their work conditions during the pandemic also facilitate doing so. The use of open areas supports health and the immune system. It is associated with better housing and street interaction, less crowding, more comfortable social distancing and higher socioeconomic levels.

\section{Conclusion}

The year 2020 was a multi-directional breaking point for health, education, work, the economy, transportation and shopping. The deaths and permanent health damage caused by COVID-19 have severely restricted the use of cities and confined most citizens to their homes. It is unclear whether it will be possible to return to the pre-COVID-19 pandemic lifestyle due to the constantly mutating virus. This indicates that pandemics and adverse situations such as disasters or wars may pose a threat to humanity in the future. Therefore, housing and residential environments must be adapted for negative situations, based on this study's results. 


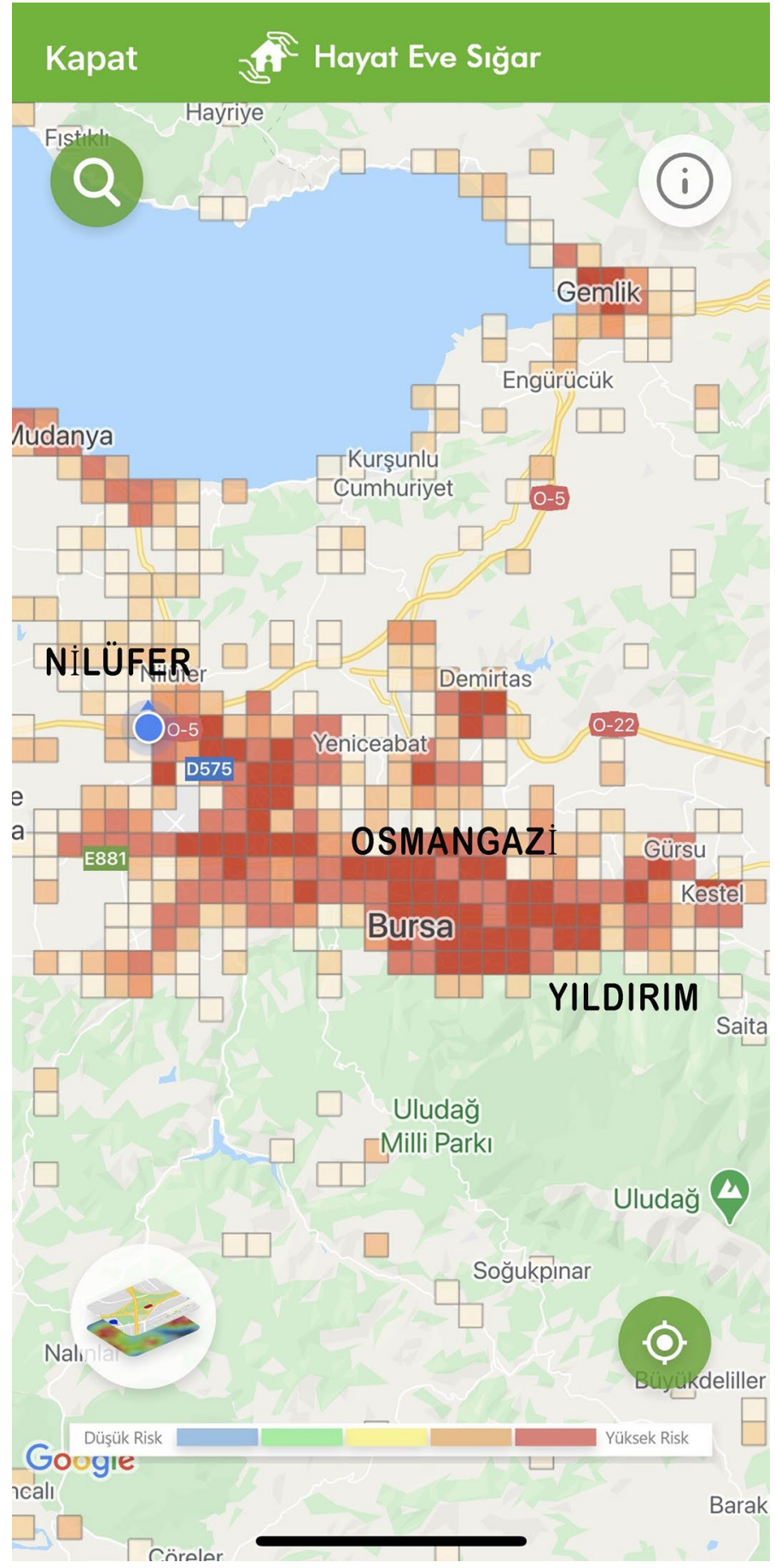

Fig. 20 December 2020 - Bursa risk map 
This study, investigating the lifestyle changes and their effects on the use of housing and residential environments during the pandemic, developed arguments about satisfying changing housing needs. In addition to general conclusions, it compared three of Bursa's districts and their residents' profiles. It found that lifestyles, especially hygiene habits, shopping behaviors, transportation habits and the frequency of contact with neighbors and friends changed during the pandemic. Flexible designs have become important because they can be used by different age groups for different purposes, including offices for distance education and remote work, for families living in twoor three-room apartments as in the case area. These solutions can be developed with partitions and modular panels, enriching the quality of life through design. Most of the participants did not have washrooms at their homes' entrances for handwashing. A good design decision under normal conditions, washrooms at the entrances of homes has become a necessity for human health. In addition, due to increased online shopping during the pandemic, most residents air out their packages. Designs that offer handwashing at the entrance, spaces for airing out packages and, if possible, changing clothes are thus very useful. Balconies and patios also increase the quality of homes. Balconies offer fresh air, and are a place of relaxation and escape for apartment residents. Flexible designs that allow balconies to be divided into multiple spaces and used for socializing are more efficient.

The use of urban green spaces declined during the pandemic, but the tendency to use open areas near the residents' homes increased. People with higher incomes have more opportunities in their residential environments, and their physical activities increased during the pandemic, positively affecting their health. In the districts where low-income residents live, the physical and social environment was less well-adapted for physical activity. Nilüfer's wealthier housing areas are less crowded and more integrated with green spaces, which makes accomodating the life of entire family in a single home or gated housing developments easier. The Nilüfer residents had greater awareness of and more compliance with COVID-19 precautions than that of residents from the other districts studied, a finding which can be attributed to differences in socio-economic status, the chance of remote working during pandemic and the level of developments in the districts. As explained in the discussion section, focus needs to be given to improving personal hygiene practices in those districts where preventive measures and social distancing are not sufficiently prioritized and where there are lower socio-economic and development levels. However, there was less remote work in Yildirim, a low-income district, and modes of transportation make it difficult to follow pandemic precautions. These dynamics, as well as the lack of green spaces, make it difficult to engage in physical activity. The district of Osmangazi, which is more crowded and socio-economically heterogeneous, is more developed than Yildirim and has urban parks that support the use of green areas and physical activities compared to other districts. In terms of the position and characteristics of neighborhoods, there is greater variability in Osmangazi. The greater number of residents engaged in remote work and the housing environments in Nilüfer, which suit private vehicles and a post-pandemic lifestyle, sheltered its residents during the pandemic. These results support each other. The findings from the study further showed that housing environments with detached houses and housing sites were more suitable for the post-pandemic lifestyle than that of apartments, and that residents could live a safer life in the post-pandemic period in districts with higher development and socio-economic status. During the pandemic, high-income residents are advantaged in terms of both lifestyle and residential environment because they have green spaces integrated into their residential environments, less crowding, and better housing and street interaction. 
This study found that the importance of housing and residential environments increased due to the pandemic. The districts' lifestyles, housing, residential environments and urban amenities are determined by socioeconomic segregation, and lower-income groups are more vulnerable to COVID-19. Socioeconomic inequalities led to inequalities in lifestyles and residential environments during the pandemic. The work and living conditions of lowincome people need to be improved. It is vital for housing and social policies to increase their awareness using technology and distance education. Awareness and knowledge can be increased by organizing workshops and seminars in disadvantaged neighborhoods in urban areas. New architectural designs and urban transformations should be adapted for healthy living, starting with more disadvantaged districts and using a compact, low-density planning approach that integrates green spaces. Housing spaces and policies should be adapted for this purpose, and the effects of potential new diseases or disasters should be mitigated by new designs and on-site changes. Considering dangers such as global warming and drought, future studies should clarify housing and residential environment design decisions in relation to approaches that support sustainable, livable and healthy urban spaces, and solutions for disadvantaged social groups. Future studies should consider potential risks to humanity and the housing problems of disadvantaged groups in Turkey. Suggestions for new residential construction can contribute to overall quality of life.

\section{Declarations}

Conflict of interest The author declares that they have no conflict of interest.

Ethical approval All procedures performed in studies involving human participants were in accordance with the ethical standards of the institutional and/or national research committee and with the 1964 Helsinki declaration and its later amendments or comparable ethical standards.

\section{References}

Adams, R. I., Bhangar, S., Dannemiller, K. C., Eisen, J. A., Fierer, N., Gilbert, J. A., Green, J. L., Marr, L. C., et al. (2016). Ten questions concerning the microbiomes of buildings. Building and Environment, 109, 224-234. https://doi.org/10.1016/j.buildenv.2016.09.001

Al Lily, A. E., Ismail, A. F., Abunasser, F. M., \& Alqahtani, R. H. A. (2020). Distance education as a response to pandemics: Coronavirus and Arab culture. Technology in Society, 63, 101317. https://doi. org/10.1016/j.techsoc.2020.101317

Alahdal, H., Basingab, F., \& Alotaibi, R. (2020). An analytical study on the awareness, attitude and practice during the COVID-19 pandemic in Riyadh, Saudi Arabia. Journal of Infection and Public Health, 13(10), 1446-1452. https://doi.org/10.1016/j.jiph.2020.06.015

Alaimo, L. S., Fiore, M., \& Galati, A. (2020). How the Covid-19 Pandemic is changing online food shopping human behaviour in Italy. Sustainability, 12(2), 1-18. https://doi.org/10.3390/su12229594

Al-Hasan, A., Khuntia, J., \& Yim, D. (2020). Threat, coping, and social distance adherence during Covİ19: Cross-continental comparison using an online cross-sectional survey. Journal of Medical Internet Research, 22(11), e23019. https://doi.org/10.2196/23019

Alqahtani, S. H. M., \& Aldawsari, M. N. R. (2015). The attitudes and degree of awareness about MERSCoV among Saudis of different ages. Clin Res Trialsi. https://doi.org/10.15761/CRT.1000114

Amérigo, M., \& Aragonés, J. I. (1997). A theoretical and methodological approach to the study of residential satisfaction. Journal of Environmental Psychology, 17(1), 47-57.

Amerio, A., Brambilla, A., Morganti, A., Aguglia, A., Bianchi, D., Santi, F., Costantini, L., Odone, A., Costanza, A., Signorelli, C., Serafini, G., Amore, M., \& Capolongo, S. (2020). Covid-19 lockdown: Housing built environment's effects on mental health. International Journal of Environmental Research and Public Health, 17(16), 5973. https://doi.org/10.3390/ijerph17165973 
Ammar, A., Chtourou, H., Boukhris, O., Trabelsi, K., Masmoudi, L., Brach, M., Bouaziz, B., et al. (2020). Covid-19 home confinement negatively impacts social participation and life satisfaction: A worldwide multicenter study. International Journal of Environmental Research and Public Health, 17(17), 6237. https://doi.org/10.3390/ijerph17176237

Andreucci, M. B., Russo, A., \& Olszewska-Guizzo, A. (2019). Designing urban green blue infrastructure for mental health and elderly wellbeing. Sustainability, 11(22), 6425. https://doi.org/10.3390/ su 11226425

Arora, N., Charm, T., Grimmelt, A., Ortega, M., Robinson, K., et al. (2020). A global view of how consumer behavior is changing amid COVID-19, a disscussion document, McKinsey \& Company, Retrieved January 19, 2021 from https://www.mckinsey.de/ /media/McKinsey/Business\%20Fun ctions/Marketing\%20and\%20Sales/Our\%20Insights/A\%20global\%20view\%20of\%20how\%20con sumer\%20behavior\%20is\%20changing\%20amid\%20COVID\%2019/20200707/covid-19-globalconsumer-sentiment-20200707.pdf

Baker, M. G., Peckham, T. K., \& Seixas, N. S. (2020). Estimating the burden of United States workers exposed to infection or disease: A key factor in containing risk of COVID-19 infection. PLoS ONE, 15, e0232452. https://doi.org/10.1371/journal.pone.0232452)

Bayrakdar, S.,\& Guveli, A. (2020). Inequalities in home learning and schools' provision of distance teaching during school closure of Covid-19 lockdown in the UK. ISER Working Paper Series, 09, University of Essex, Institute for Social and Economic Research (ISER), Colchester.

Bonaiuto, M., Fornara, F., \& Bonnes, M. (2003). Indexes of perceived residential environment quality and neighbourhood attachment in urban environments: A confirmation study on the city of Rome. Landscape and Urban Planning, 65(1-2), 41-52. https://doi.org/10.1016/S0169-2046(02)00236-0

Brom, C., Lukavský, J., David, G., Hannemann, T., Straková, J., \& Švaříček, R. (2020). Mandatory home education during the Covid-19 lockdown in the Czech Republic: A rapid survey of 1st-9th graders' parents. Frontiers in Education, 5, 1-8. https://doi.org/10.3389/feduc.2020.00103

Çakiroğlu, K.I., Pirtini, S.,\& Çengel, Ö. (2020). Covid-19 sürecinde ve post-pandemi döneminde yaşam tarzi açisindan tüketici davranişlarinin değişen eğilimi üzerine kavramsal bir çalişma. Istanbul Ticaret Üniversitesi Sosyal Bilimler Dergisi, 37 (Special Issue), 81-103.

Çalişkan, Ş. (2010). Türkiye'de Gelir Eşitsizliği ve Yoksulluk. Sosyal Siyaset Konferanslari Dergisi, 59, 89-132.

Calvo, K.,\& Bejarano, E. (2020). Music, solidarities and balconies in Spain. Interface: A Journal for and about Social Movements, Sharing stories of struggles, 1-7.

Capolongo, S., Rebecchi, A., Buffoli, M., Appolloni, L., Signorelli, C., Fara, G. M., \& D’Alessandro, D. (2020). Covid-19 and cities: from urban health strategies to the pandemic challenge A decalogue of public health opportunities. Acta Bio-Medica, 91(2), 13-22. https://doi.org/10.23750/abm.v91i2. 9615

Chen, E., Kaczmarek, K., \& Ohyama, H. (2020). Student perceptions of distance learning strategies during COVID-19. Journal of Dental Education, Advance Online Publication. https://doi.org/10.1002/ jdd. 12339

D’Alessandro, D., Gola, M., Appolloni, L., Dettori, M., Fara, G. M., Rebecchi, A., Settimo, G., \& Capolongo, S. (2020). COVID-19 and Living space challenge Well-being and Public Health recommendations for a healthy safe and sustainable housing. Acta Bio Medica Atenei Parmensis, 91(9), 61-75. https://doi.org/10.23750/abm.v91i9-S.10115

Demirdöğmez, M., Taş, H. Y., \& Gültekin, N. (2020). Koronavirüs' ün (Covid-19) e-ticarete etkileri. OPUS Uluslararasi Toplum Araştirmalari Dergisi-International Journal of Society Researches, 16(29), 125-144. https://doi.org/10.26466/opus.734447

Di Renzo, L., Gualtieri, P., Pivari, F., Soldati, L., Attinà, A., et al. (2020). Eating habits and lifestyle changes during COVID-19 lockdown: An Italian survey. Journal of Translational Medicine, 18(1), 229. https://doi.org/10.1186/s12967-020-02399-5

Dietz, L., Horve, P. F., Coil, D. A., Fretz, M., Eisen, J. A., \& Van Den Wymelenberg, K. (2020). Novel coronavirus (Covid-19) pandemic: Built environment considerations to reduce transmission. Msystems, 5(2), e00245-e320. https://doi.org/10.1128/mSystems.00245-20

Edwards, P.,\& Tsouros, A. D., (2008). A Healthy City is an Active City: A Physical Activity Planning Guide. WHO Regional Office for Europe, Copenhagen, Denmark.

Eger, L., Komárková, L., Egerová, D., \& Mičík, M. (2021). The effect of COVID-19 on consumer shopping behaviour: Generational cohort perspective. Journal of Retailing and Consumer Services, 61. https:// doi.org/10.1016/j.jretconser.2021.102542

Ellis, W. E., Dumas, T. M., \& Forbes, L. M. (2020). Physically isolated but socially connected: Psychological adjustment and stress among adolescents during the initial COVID-19 crisis. Canadian Journal of Behavioural Science, 52(3), 177-187. https://doi.org/10.1037/cbs0000215) 
Estabrooks, P. A., Lee, R. E., \& Gyurcsik, N. C. (2003). Resources for physical activity participation: Does availability and accessibility differ by neighborhood socioeconomic status? Annals of Behavioral Medicine, 25(2), 100-104. https://doi.org/10.1207/S15324796ABM2502_05

Fernandes, N., (2020, March 22). Economic Effects of Coronavirus Outbreak (COVID-19) on the World Economy. IESE Business School Working Paper No. Retrieved November 11, 2020,WP-1240-E, http://dx.doi.org/https://doi.org/10.2139/ssrn.3557504

Garber, M. (2020). Homes actually need to be practical now: One of the ironies of social distancing is that it can put privacy in short supply. The Atlantic. Retrieved April 11, 2020, from https://www.theatlantic. com/culture/archive/2020/03/finding-privacy-during-pandemic/608944/

Giles-Corti, B., \& Donovan, R. J. (2002). Socioeconomic status differences in recreational physical activity levels and real and perceived access to a supportive physical environment. Preventive Medicine, 35(6), 601-611. https://doi.org/10.1006/pmed.2002.1115

Głąbska, D., Skolmowska, D., \& Guzek, D. (2020). Population-based study of the influence of the Covid19 Pandemic on hand hygiene behaviors-Polish adolescents' Covid-19 experience (place-19) study. Sustainability, 12, 4930.

Gondauri, D., Mikautadze, E., \& Batiashvili, M. (2020). Research on COVID-19 virus spreading statistics based on the examples of the cases from different countries. Electronic Journal of General Medicine, 17(4), 1-4. https://doi.org/10.29333/ejgm/7869

Greenberg, N. (2020). Mental health of health-care workers in the COVID-19 era. Nature Reviews Nephrology, 16, 425-426. https://doi.org/10.1038/s41581-020-0314-5

Guilomoto C.Z.,\& Licart T. (2020). India and coronavirus: lack of access to handwashing facilities among poor makes fight even harder, The Conversation, April 1,2020, Retrieved December 10, 2020, from https://theconversation.com/india-and-coronavirus-lack-of-access-to-handwashing-facil ities-among-poor-makes-fight-even-harder-135087

Gür, M., (2015). Kentsel Dönüşüm Uygulamasinda Yaşam Kalitesi Araştirmasi ve Kavramsal bir Model Önerisi Bursa Doğanbey Örne ği. AKMAT Akinoğlu Matbaacilik, Bursa, Türkiye.

Gür, M., \& Erbil, Y. (2018). Konut ve konut çevresine ilişkin kullanici memnuniyeti araştirmasi: Bursa/ Yildirim. Journal of Social Humanities Sciences Research, 5(30), 4135-4148. https://doi.org/10. 26450/jshsr.936

Gür, M., Murat, D. \& Sezer, F. Ş. (2020). The effect of housing and neighborhood satisfaction on perception of happiness in Bursa, Turkey. Journal of Housing and the Built Environment, 35, 679-697. https://doi. org/10.1007/s10901-019-09708-512

Hashem, T. N. (2020). Examining the influence of covid 19 pandemic in changing customers' orientation towards e-shopping. Modern Applied Science, 14(5), 59-76. https://doi.org/10.5539/mas.v14n8p59

Hebebci, M. T., Bertiz, Y., \& Alan, S. (2020). Investigation of views of students and teachers on distance education practices during the coronavirus (Covid-19) pandemic. International Journal of Technology in Education and Science, 4(4), 267-282.

Hipwood, T. (2020). The end of open-plan living? How Covid-19 is changing our homes. Retrieved January 12, 2021 from https:/www.fastcompany.com/90515499/the-end-of-open-plan-living-how-covid-19-ischanging-our-homes

Honey-Rosés, J., Anguelovski, I., Chireh, V. K., Daher, C. K., van den Bosch, C., Litt, J. S., et al. (2020). The impact of COVID-19 on public space: An early review of the emerging questions-design, perceptions and inequities. Cities \& Health. https://doi.org/10.1080/23748834.2020.178007

https://www.cdc.gov, Access Date: October 11, 2020

Jenelius, E., \& Cebecauer, M. (2020). Impacts of COVID-19 on public transport ridership in Sweden: Analysis of ticket validations, sales and passenger counts. Transportation Research Interdisciplinary Perspectives, 8, 1-8. https://doi.org/10.1016/j.trip.2020.100242

Jones, A., \& Grigsby-Toussaint, D. S. (2020). Housing stability and the residential context of the COVID-19 pandemic. Cities\&health. https://doi.org/10.1080/23748834.2020.1785164

Kayabaşi, E. T. (2020). Covid-19'un piyasalara ve tüketici davranişlarina etkisi. Eurasian Journal of Researches in Social and Economics (EJRSE), 7(5), 15-25.

Kembel, S. W., Meadow, J. F., O’Connor, T. K., Mhuireach, G., Northcutt, D., Kline, J., et al. (2014). Architectural design drives the biogeography of indoor bacterial communities. PLoS ONE, 9(1), e87093. https://doi.org/10.1371/journal.pone.0087093

López Moreno, M., López, M. T. I., Miguel, M., \& Garcés-Rimón, M. (2020). Physical and psychological effects related to food habits and lifestyle changes derived from Covid-19 home confinement in the Spanish population. Nutrients, 12(11), 3445. https://doi.org/10.3390/nu12113445

Mattioli, A. V., Sciomer, S., Cocchi, C., Maffei, S., \& Gallina, S. (2020). Quarantine during Covid-19 outbreak: Changes in diet and physical activity increase the risk of cardiovascular disease. Nutrition, 
Metabolism \& Cardiovascular Diseases, 30, 1409-1417. https://doi.org/10.1016/j.numecd.2020.05. 020

Mcmurray, R. G., Harrell, J. S., Deng, S., Bradley, C. B., Cox, L. M., \& Bangdiwala, S. I. (2000). The influence of physical activity, socioeconomic status, and ethnicity on the weight status of adolescents. Obesity Research, 8, 130-139.

Megahed, N. A., \& Ghoneim, E. M. (2020). Antivirus-built environment: Lessons learned from Covid-19 pandemic. Sustainable Cities and Society. https://doi.org/10.1016/j.scs.2020.102350

Molloy, J., Tchervenkov, C., Schatzmann, T., Schoeman, B., Hintermann, B.,\& Axhausen, K.W. (2020). MOBIS-COVID19/25 Results as of 19/10/2020, Working Paper, ETH Zurich Research Collection, Retrieved January 16,2021 from https://www.research-collection.ethz.ch/handle/20.500.11850/ 447684. https://doi.org/10.3929/ethz-b-000447684

Mutlu, E., \& Varol, Ç. (2017). Sosyo-ekonomik farklilaşma ve mekânsal ayrişma: Bursa metropoliten alani analizi. Megaron, 12(1), 87-105. https://doi.org/10.5505/megaron.2016.04695

Nooh, H. Z., Alshammary, R. H., Alenezy, J. M., Alrowaili, N. H., Alsharari, A. J., Alenzi, N. M., \& Sabaa, H. E. (2020). Public awareness of coronavirus in Al-Jouf region Saudi Arabia. Journal of Public Health. https://doi.org/10.1007/s10389-020-01209-y

Olivier, L. E., Botha, S., \& Craig, I. K. (2020). Optimized lockdown strategies for curbing the spread of covid-19: A South African case study. IEEE Access, 8, 205755-205765. https://doi.org/10.1109/ ACCESS.2020.3037415

Oluwatosin, A. A., Olugbemiga, O. S., Olugbenga, A. T., Ajibade, S. M., \& Moveh, S. (2020). Housing quality standard and Covid-19 pandemic: A call for attention in Nigeria. Journal of Science, Engineering Technology and Management, 01(01), 44-53. https://doi.org/10.46820/JSETM.2020.1105

Owen, A. J., Tran, T., Hammarberg, K., Kirkman, M., Fisher, J., \& COVID-19 Restrictions Impact Research Group. (2021). Poor appetite and overeating reported by adults in Australia during the coronavirus-19 disease pandemic: A population-based study. Public Health Nutrition, 24(2), 275-281. https://doi.org/ 10.1017/S1368980020003833

Ozili, P. K., \& Arun, T. (2020). Spillover of COVID-19: Impact on the global economy. SSRN. https://doi. org/10.2139/ssrn. 3562570

Peters, T.,\& Halleran, A. (2020). How our homes impact our health: using a COVID-19 informed approach to examine urban apartment housing. Archnet-IJAR, (ahead-of-print). https://doi.org/10.1108/ ARCH-08-2020-0159

Phillipou, A., Meyer, D., Neill, E., et al. (2020). Eating and exercise behaviors in eating disorders and the general population during the Covid-19 pandemic in Australia: Initial results from the COLLATE project. International Journal of Eating Disorders. https://doi.org/10.1002/eat.23317

Pieh, C., Budimir, S., \& Probst, T. (2020). The effect of age, gender, income, work, and physical activity on mental health during coronavirus disease (COVID-19) lockdown in Austria. Journal of Psychosomatic Research. https://doi.org/10.1016/j.jpsychores.2020.110186

Poon, L. (2020). A Lesson from social distancing: build better balconies, Retrieved November 17, 2020, from https://www.bloomberg.com/news/articles/2020-04-20/lesson-from-coronavirus-build-betterbalconies

Qiu, J., Shen, B., \& Zhao, M. (2020). A nationwide survey of psychological distress among Chinese people in the COVID-19 epidemic: Implications and policy recommendations. General Psychiatry, 2020(33), e100213. https://doi.org/10.1136/gpsych-2020-100213

Reyes-Olavarría, D., Latorre-Román, P. A., Guzmán-Guzmán, I. P., Jerez-Mayorga, D., Caamaño-Navarrete, F., \& Delgado-Floody, P. (2020). Positive and negative changes in food habits, physical activity patterns and weight status during Covid-19 confinement: Associated factors in the Chilean population. International Journal of Environment Research Public Health, 17(15), 5431. https://doi.org/10.3390/ ijerph17155431

Rogers, D., \& Power, E. (2020). Housing policy and the COVID-19 pandemic: The importance of housing research during this health emergency. International Journal of Housing Policy, 20(2), 177-183. https://doi.org/10.1080/19491247.2020.1756599

Sadiq, A., Saleem, M. S., Malik, M., Malik, M. I., Akhtar, F. K., \& Waheed, K. (2020). How Covid-19 is changing behaviors of population: A study from Punjab? Biomédica, 36, 253-259.

Sakr, S., Ghaddar, A., Sheet, I., \& Bassam, H. (2020). Knowledge, attitude and practices related to COVID19 among young Lebanese population. Research Square. https://doi.org/10.21203/rs.3.rs-80033/v1

Salama, A. M. (2020). Coronavirus questions that will not go away: interrogating urban and socio-spatial implications of COVID-19 measures. Emerald Open Research, 2, 14. https://doi.org/10.35241/emera ldopenres.13561.1

Sarla, G. S. (2020). COVID 19: Myths and facts. Journal of Research\&review: Manage-Ment of Emergency and Trauma Nursing, 2(2), 5-8. https://doi.org/10.5281/zenodo.3742655 
Sennett, R., (2020). Cities in the Pandemic, Retrieved November 11,2020, from https://www.publicspace. org/multimedia/-/post/cities-in-the-pandemic

Settersten, R. A., Bernardi, L., Härkönen, J., Antonucci, T. C., Dykstra, P. A., et al. (2020). Understanding the effects of Covid-19 through a life course lens. Advances in Life Course Research. https://doi.org/ 10.1016/j.alcr.2020.100360

Setti, L., Passarini, F., De Gennaro, G., Barbieri, P., Perrone, M., Borelli, M., et al. (2020). Airborne transmission route of COVID-19: Why 2 meters/6 feet of interpersonal distance could not be enough. International Journal of Environmental Research and Public Health, 17(8), 2932. https://doi.org/10.3390/ ijerph17082932

Shenker, J. (2020). Cities after coronavirus: how Covid-19 could radically alter urban life. The Guardian. Retrieved September 29, 2020, from https://www.theguardian.com/world/2020/mar/26/life-after-coron avirus-pandemic-change-world

Signorelli, C., Capolongo, S., D'Alessandro, D., \& Fara, G. M. (2020). The homes in the COVID-19 era How their use and values are changing. Acta Bio-Medica, 91(9-S), 92-94. https://doi.org/10.23750/ abm.v91i9-S.10125

Sindiani, A. M., Obeidat, N., Alshdaifat, E., Elsalem, L., Alwani, M. M., et al. (2020). Distance education during the COVID-19 outbreak: A cross-sectional study among medical students in North of Jordan. Annals of Medicine and Surgery, 59, 186-194. https://doi.org/10.1016/j.amsu.2020.09.036

Sy, K., Martinez, M. E., Rader, B., \& White, L. F. (2020). Socioeconomic disparities in subway use and COVID-19 outcomes in New York City. medRxiv, the preprint server for health sciences. https://doi. org/10.1101/2020.05.28.20115949

Talevi, D., Socci, V., Cara, M., Carnaghi, G., Faleri, S., Trebbi, E., Di Bernardo, A., Capelli, C., \& Pacitti, F. (2020). Mental health outcomes of the CoViD-19 pandemic. Rivista Di Psichiatria, 55(3), 137-144. https://doi.org/10.1708/3382.33569

Türkoğlu, H. (2020). Covid-19 sonrasi kentler ve kent planlama, Türkiye Sağlikli Kentler Birliği Retrieved November 17, 2020, from http://www.skb.gov.tr/wp-content/uploads/2020/09/COVID-19-SonrasiKent-ve-Kent-Planlama-Prof.-Dr.-Handan-Turkoglu.pdf

Türkoğlu, H. D. (1997). Residents' satisfaction of housing environments: The case of Istanbul. Turkey, Landscape and Urban Planning, 39(1), 55-67.

Wang, C., Pan, R., Wan, X., Tan, Y., Xu, L., Ho, C. S., \& Ho, R. C. (2020). Immediate psychological responses and associated factors during the initial stage of the 2019 coronavirus disease (Covid-19) epidemic among the general population in China. International Journal of Environmental Research and Public Health, 17(5), 1729. https://doi.org/10.3390/ijerph17051729

Weill, J. A., Stigler, M., Deschenes, O., \& Springborn, M. R. (2020). Social distancing responses to COVID19 emergency declarations strongly differentiated by income. Proceedings of the National Academy of Sciences, 117(33), 19658-19660. https://doi.org/10.1073/pnas.2009412117

Wise, T., Zbozinek, T. D., Michelini, G., Hagan, C. C., \& Mobbs, D. (2020). Changes in risk perception and self-reported protective behaviour during the first week of the COVID-19 pandemic in the United States. Royal Society Open Science, 7, 200742. https://doi.org/10.1098/rsos.200742

WHO. (2020). Rational use of personal protective equipment for coronavirus disease 2019 (COVID-19). Interim guidance. Retrieved December 31, 2020, from https://www.who.int/publications/i/item/ratio nal-use-of-personal-protective-equipment-for-coronavirus-disease-(covid-19)-and-considerations-during-severe-shortages

Yao, H., Chen, J. H., \& Xu, Y. F. (2020). Patients with mental health disorders in the COVID-19 epidemic. The Lancet, 7(4), e21. https://doi.org/10.1016/S2215-0366(20)30090-0

Yılmaz, F., Acar, S., Bilen Kazancık, L., Gültekin, L., Meydan, M. C., Özsan, M. E.,\& Işık, M. (2019). İlçelerin Sosyo-Ekonomik Gelişmişlik Sıralaması 2017. T.R. The Ministry of Industry and Technology, Retrieved July 10, 2021, from https://www.bebka.org.tr/admin/datas/sayfas/89/lce-sege-2017_15982 65107.pdf

Zegarra-Valdivia, J., Chino Vilca, B. N., \& Ames-Guerrero, R. J. (2020). Knowledge, perception and attitudes in Regard to COVID-19 Pandemic in Peruvian Population (2020, April 16). PsyArXiv. https:// doi.org/10.17605/OSF.IO/F57X9

Publisher's Note Springer Nature remains neutral with regard to jurisdictional claims in published maps and institutional affiliations. 